Article

\title{
Ruthenium $\left(\eta^{6}, \eta^{1}\right.$-arene- $\left.\mathrm{CH}_{2}-\mathrm{NHC}\right)$ Catalysts for Direct Arylation of 2-Phenylpyridine with (Hetero)Aryl Chlorides in Water
}

\author{
Nazan Kaloğlu 1,2, İsmail Özdemir 1,2,*(1), Nevin Gürbüz ${ }^{1,2}$ (D) , Hakan Arslan ${ }^{3}$ (1) and \\ Pierre H. Dixneuf ${ }^{4}$ \\ 1 Department of Chemistry, Faculty of Science and Arts, İnönü University, 44280 Malatya, Turkey; \\ nzntemelli@hotmail.com (N.K.); nevin.gurbuz@inonu.edu.tr (N.G.) \\ 2 Catalysis Research and Application Center, İnönü University, 44280 Malatya, Turkey \\ 3 Faculty of Arts and Science, Department of Chemistry, Mersin University, 33343 Mersin, Turkey; \\ hakan.arslan@mersin.edu.tr \\ 4 Institut des Sciences Chimiques de Rennes, Université de Rennes 1, 35042 Rennes, France; \\ pierre.dixneuf@univ-rennes1.fr \\ * Correspondence: ismail.ozdemir@inonu.edu.tr; Tel./Fax: +90-422-341-0212
}

Received: 16 February 2018; Accepted: 7 March 2018; Published: 13 March 2018

\begin{abstract}
A series of new benzimidazolium halides were synthesized in good yields as unsymmetrical $\mathrm{N}$-heterocyclic carbene ( $\mathrm{NHC}$ ) precursors containing the $\mathrm{N}-\mathrm{CH}_{2}$-arene group. The benzimidazolium halides were readily converted into ruthenium(II)-NHC complexes with the general formula $\left[\mathrm{RuCl}_{2}\left(\eta^{6}, \eta^{1}\right.\right.$-arene- $\left.\left.\mathrm{CH}_{2}-\mathrm{NHC}\right)\right]$. The structures of all new compounds were characterized by ${ }^{1} \mathrm{H}$ NMR (Nuclear Magnetic Resonance), ${ }^{13}$ C NMR, FT-IR (Fourier Transform Infrared) spectroscopy and elemental analysis techniques. The single crystal structure of one benzimidazole ruthenium complex, $\mathbf{2 b}$, was determined. The complex is best thought of as containing an octahedrally coordinated $\mathrm{Ru}$ center with the arene residue occupying three sites, the remaining sites being occupied by a (carbene)C-Ru bond and two $\mathrm{Ru}-\mathrm{Cl}$ bonds. The catalytic activity of $\left[\mathrm{RuCl}_{2}\left(\eta^{6}, \eta^{1}\right.\right.$-arene- $\left.\left.\mathrm{CH}_{2}-\mathrm{NHC}\right)\right]$ complexes was evaluated in the direct (hetero)arylation of 2-phenylpyridine with (hetero)aryl chlorides in water as the nontoxic reaction medium. These results show that catalysts $2 \mathbf{a}$ and $\mathbf{2 b}$ were the best for monoarylation with simple phenyl and tolyl chlorides. For functional aryl chlorides, $\mathbf{2 d}, \mathbf{2 e}$, and $\mathbf{2 c}$ appeared to be the most efficient.
\end{abstract}

Keywords: homogeneous catalysis; ruthenium; $N$-heterocyclic carbene; 2-phenylpyridine; direct arylation; single crystal structure

\section{Introduction}

The prevalence and importance of biaryl compounds in natural products, advanced materials, and pharmaceuticals have made the preparation of $\mathrm{C}\left(\mathrm{sp}^{2}\right)-\mathrm{C}\left(\mathrm{sp}^{2}\right)$ bond among the core interests of organic synthesis [1]. Transition metal-catalyzed cross-coupling reactions of aromatic compounds are useful synthetic routes to biaryl compounds [2-7]. By far, traditional transition metal-catalyzed biaryl cross-coupling reactions, which generally employ aryl halides and organometallics as coupling partners, have served as the most common methods for constructing biaryl unions (Figure 1a) [8,9]. Despite the large scope of reactions and opportunities opened by these traditional methodologies, the starting organometallic reagents are often not commercially available. Moreover, the amount of byproducts produced, whether in the synthesis of the organometallic reagent or during the coupling step itself, remains significant. Recently, there has been much interest in transition metal-catalyzed direct cross-coupling $\mathrm{C}-\mathrm{C}$ bond formation of aromatic compounds with aryl halides as electrophilic 
partners involving the activation of normally unreactive aromatic $\mathrm{C}-\mathrm{H}$ bond, in terms of synthesis efficiency and minimization of reaction steps waste (Figure 1b) [10-12]. Therefore, direct arylation reactions through cleavage of $\mathrm{C}-\mathrm{H}$ bonds represent an environmentally and economically more attractive strategy.

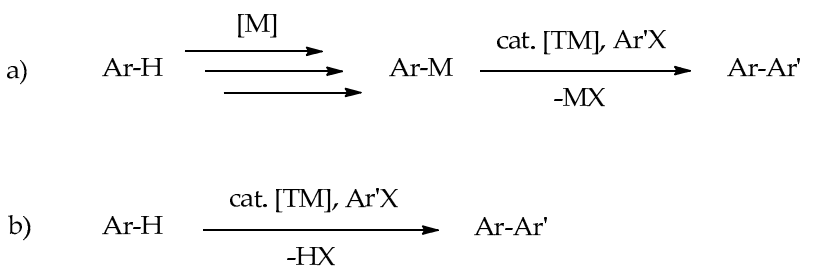

Figure 1. Coupling reactions: (a) Traditional cross-coupling; and (b) direct arylation.

The direct $\mathrm{C}-\mathrm{C}$ bond formation reactions generally involve directing-group-assisted activation of $\mathrm{sp}^{2} \mathrm{C}-\mathrm{H}$ bonds of ortho aromatic $\mathrm{C}-\mathrm{H}$ bonds. Many directing groups, such as acetyl, acetamino, carboxylic acid, oxazolyl, pyridyl, hydroxyl, imino, and cyano moieties, have been used for $\mathrm{C}-\mathrm{H}$ bond activation [13-24]. The first example of a functional group assisted ruthenium-catalyzed C-H bond functionalization was reported by Lewis in 1986 [25]. Further pioneering work by Murai, Kakiuchi and Chatani on ruthenium-catalyzed hydroarylations showed the ability of ruthenium catalysts to activate C-H bonds selectively, via assistance of a coordinating functional group [26]. In 2001, the first ruthenium(II)-catalyzed chelation-assisted direct arylation with aryl bromides was performed by Oi, Inoue and co-workers [27]. In addition, Prades and Peris also reported the acetate-assisted arylation of 2-phenylpyridine using $N$-heterocyclic carbene-ruthenium complexes [28].

Recently, different direct arylations catalysed by ruthenium-based complexes have been described by the groups of Ackermann [29-31], Dixneuf [32], Davies [33] and others [34-38]. Several ruthenium-catalyzed direct arylations were also reported by our group [39-41]. Most of these reported direct arylations were performed either in NMP ( $N$-methyl-2-pyrrolidone) or toluene as solvent. However, the demand for a more environmentally friendly chemistry opens a new horizon for the extended application of "green solvents" in direct C-H bond functionalizations as well [42]. In this connection, several ruthenium-catalyzed direct arylations in water or diethylcarbonate (DEC) as green solvent using an additive were reported by Dixneuf's group [43-49].

We now described the synthesis and characterization of new unsymmetrical benzimidazolium halides (1a-e) and five new ruthenium(II) complexes of the general formula $\left[\mathrm{RuCl}_{2}\left(\eta, \eta^{6}-1\right.\right.$-arylmethyl-3-butylbenzimidazol-2-ylidene)] (2a-e). All new compounds were characterized by ${ }^{1} \mathrm{H}$ NMR, ${ }^{13} \mathrm{C}$ NMR, FT-IR spectroscopy and elemental analysis techniques. The single crystal structure of the benzimidazole ruthenium complex $\mathbf{2} \mathbf{b}$ was also determined. These new complexes with KOAc partner were evaluated as catalyst precursors for the direct mono orthoarylation of 2-phenylpyridine with (hetero)aryl chlorides in water, without the need of surfactant.

\section{Results and Discussion}

\subsection{Preparation of Benzimidazolium Halides}

Benzimidazolium halides $\mathbf{1 a}, \mathbf{1} \mathbf{b}, \mathbf{1 d}$ and $\mathbf{1 e}$ were synthesized by reacting $N$-(alkyl)benzimidazole with alkyl halide in dimethylformamide (DMF) at $80^{\circ} \mathrm{C}$ for $24 \mathrm{~h}$. The benzimidazolium chloride $1 \mathrm{c}$ was obtained as we previously described [40]. These products were isolated as crystalline solids in high yields (78-87\%). The benzimidazolium halides 1a-e are air- and moisture-stable both in the solid state and in solution and are soluble in chlorinated solvents, ethyl alcohol and water (Scheme 1). The benzimidazolium halides were characterized using ${ }^{1} \mathrm{H}$ NMR, ${ }^{13} \mathrm{C}$ NMR, and FT-IR spectroscopy and gave satisfactory elemental analysis. The FT-IR data clearly indicated that the benzimidazolium halides 1a-e exhibit a characteristic $v_{(\mathrm{NCN})}$ band typically between $1553-1560 \mathrm{~cm}^{-1}$. In the ${ }^{13} \mathrm{C} N M R$ 
spectra of compounds 1a-e, the characteristic peak of the imino carbon (NCHN) resonance was detected in the area $\delta$ 143.2-143.6 ppm. The ${ }^{1} \mathrm{H}$ NMR spectra of compounds $\mathbf{1 a}, \mathbf{1 b}, \mathbf{1 d}$ and $\mathbf{1 e}$ further supported the assigned structures. The resonances for $\mathrm{C}(2)-H$ were observed as sharp singlets at $\delta$ 10.53-11.53 ppm and consistent with NMR values of other benzimidazolium halides [50].
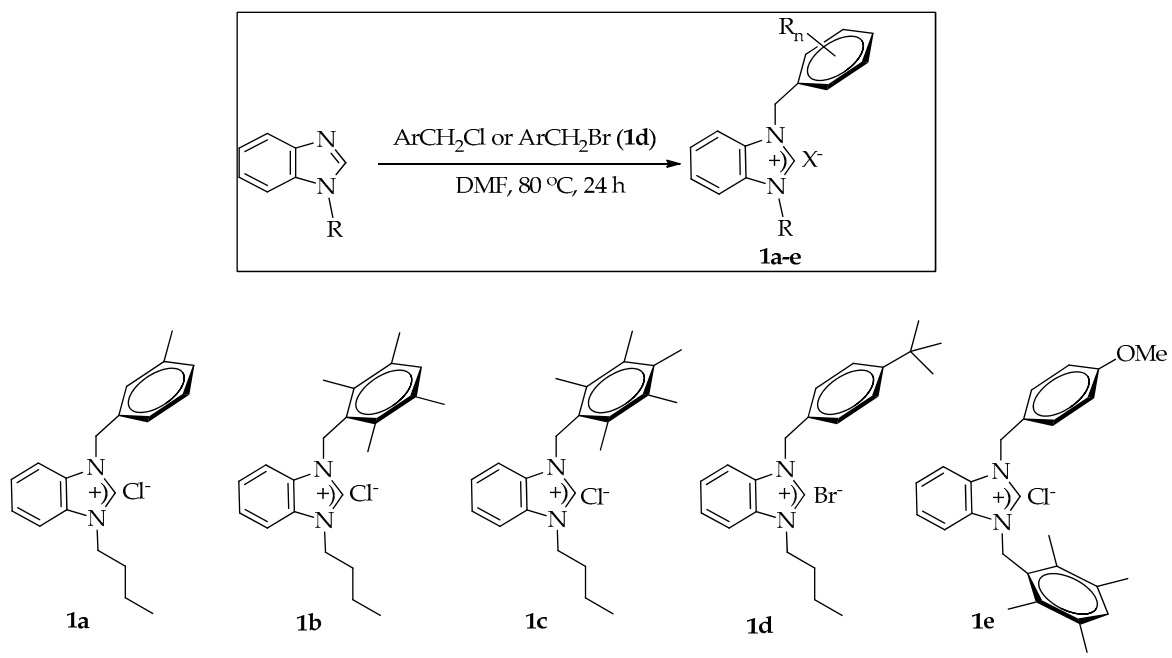

Scheme 1. Synthesis of benzimidazolium halides, 1a-e.

\subsection{Preparation of Ruthenium(II)-NHC Complexes Containing the $\eta^{6}, \eta^{1}-$ NHC Mixed Chelating Ligand}

The carbene ligands formed by deprotonation of benzimidazolium salts 1a-e using $\mathrm{Cs}_{2} \mathrm{CO}_{3}$ were reacted with $\left[\mathrm{RuCl}_{2}(p-c y m e n e)\right]_{2}$ in toluene at $110{ }^{\circ} \mathrm{C}$ for $5 \mathrm{~h}$ to give good yield of $\left[\mathrm{RuCl}_{2}\left(\eta^{6}, \eta^{1}-1\right.\right.$-arylmethyl-3-butylbenzimidazol-2-ylidene)] (Scheme 2). Selective crystallization by solvent diffusion technique $\left(\mathrm{CH}_{2} \mathrm{Cl}_{2} /\right.$ Hexane) allowed the formation of suitable orange-brown crystalline solids in yields of 70-82\%. The air- and moisture-stable complexes $2 \mathbf{a}-\mathbf{e}$ are soluble in solvents such as dichloromethane, chloroform, toluene, and tetrahydrofuran. The ruthenium(II)-NHC complexes 2a-e were characterized using ${ }^{1} \mathrm{H}$ NMR, ${ }^{13} \mathrm{C}$ NMR, and FT-IR spectroscopy and gave satisfactory elemental analysis. The FT-IR data clearly indicated that the exhibit a characteristic $v_{(\mathrm{NCN})}$ band typically within 1400-1407 $\mathrm{cm}^{-1}$. NMR analysis confirmed the loss of the $p$-cymene ligand and the coordination of the (arene- $\mathrm{CH}_{2}-\mathrm{NHC}$ )arene. ${ }^{13} \mathrm{C} \mathrm{NMR}$ chemical shifts provide a useful diagnostic tool for this type of metal carbene complex. The chemical shifts for the carbene carbon atom are located in $\delta 181.3-185.2 \mathrm{ppm}$ range and are similar to those found in other ruthenium(II)-NHC complexes [51]. The analytical data are in good agreement with the compositions proposed for all the compounds we prepared, and are summarized in Table 1.

Table 1. Physical and spectroscopic properties of new compounds $\mathbf{1}$ and 2.

\begin{tabular}{clccccc}
\hline Compound & Formula & $\begin{array}{c}\text { Isolated } \\
\text { Yield (\%) }\end{array}$ & $\begin{array}{c}\text { M.p. } \\
\text { (Metlting } \\
\text { Point) }\left({ }^{\circ} \mathbf{C}\right)\end{array}$ & $\begin{array}{c}\text { v(CN) } \\
\text { (Frequency) } \\
\left.\text { (cm }{ }^{-1}\right)\end{array}$ & $\begin{array}{c}{ }^{\mathbf{1}} \mathbf{H} \text { NMR } \\
\mathbf{H}(\mathbf{2}) \text { (ppm) }\end{array}$ & $\begin{array}{c}{ }^{\mathbf{1 3}} \mathbf{C} \text { NMR } \\
\mathbf{C}(\mathbf{2}) \\
(\mathbf{p p m})\end{array}$ \\
\hline $\mathbf{1 a}$ & $\mathrm{C}_{19} \mathrm{H}_{23} \mathrm{ClN}_{2}$ & 78 & $198-199$ & 1558 & 11.49 & 143.2 \\
$\mathbf{1 b}$ & $\mathrm{C}_{22} \mathrm{H}_{29} \mathrm{ClN}_{2}$ & 83 & $176-177$ & 1553 & 10.86 & 142.9 \\
$\mathbf{1 d}$ & $\mathrm{C}_{22} \mathrm{H}_{29} \mathrm{BrN}_{2}$ & 80 & $184-185$ & 1560 & 11.45 & 142.6 \\
$\mathbf{1 e}$ & $\mathrm{C}_{26} \mathrm{H}_{29} \mathrm{ClN}_{2} \mathrm{O}$ & 87 & $191-192$ & 1557 & 11.53 & 143.6 \\
$\mathbf{2 a}$ & $\mathrm{C}_{19} \mathrm{H}_{22} \mathrm{Cl}_{2} \mathrm{~N}_{2} \mathrm{Ru}$ & 87 & $231-232$ & 1401 & - & 181.3 \\
$\mathbf{2 b}$ & $\mathrm{C}_{22} \mathrm{H}_{28} \mathrm{Cl}_{2} \mathrm{~N}_{2} \mathrm{Ru}$ & 80 & $311-312$ & 1400 & - & 184.9 \\
$\mathbf{2 c}$ & $\mathrm{C}_{23} \mathrm{H}_{30} \mathrm{Cl}_{2} \mathrm{~N}_{2} \mathrm{Ru}$ & 82 & $319-320$ & 1406 & - & 186.0 \\
$\mathbf{2 d}$ & $\mathrm{C}_{22} \mathrm{H}_{28} \mathrm{Cl}_{2} \mathrm{~N}_{2} \mathrm{Ru}$ & 71 & $298-299$ & 1403 & - & 186.1 \\
$\mathbf{2 e}$ & $\mathrm{C}_{26} \mathrm{H}_{28} \mathrm{Cl}_{2} \mathrm{~N}_{2} \mathrm{ORu}$ & 76 & $310-311$ & 1407 & - & 185.2 \\
\hline
\end{tabular}



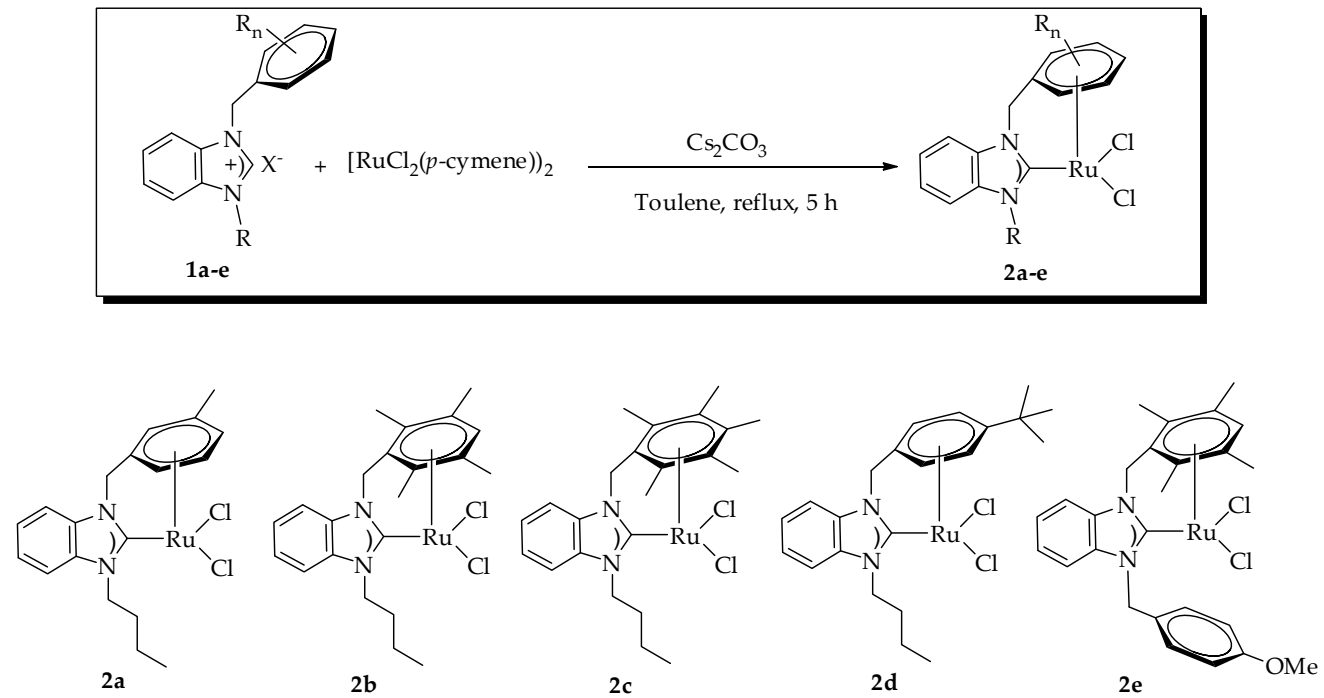

Scheme 2. Synthesis of $\left[\mathrm{Ru}-\mathrm{Cl}_{2}\left(\eta^{6}, \eta^{\mathbf{1}}\right.\right.$-arene- $\left.\left.\mathrm{CH}_{2}-\mathrm{NHC}\right)\right]$ complexes, $\mathbf{2 a}-\mathbf{e}$.

\subsection{Single Crystal X-ray Diffraction and Structure Analysis of Complex $\mathbf{2 b}$}

The ligand in compound $\mathbf{2} \mathbf{b}$ has both benzimidazolylidene and arene rings, which are connected chelating via a $\mathrm{CH}_{2}$ bridge (Figure 2). Further details concerning data collection and refinements are given in the Supplementary Materials. This configuration leads to a system with very little apparent strain on coordinating the ruthenium atom. The complex is best described as containing an octahedrally coordinated Ru center with the arene residue occupying three sites, the remaining sites being occupied by an $\mathrm{Ru}-\mathrm{C}$ (carbene) bond, derived from the benzimidazole ring, and two $\mathrm{Ru}-\mathrm{Cl}$ bonds. The small steric demand of the benzimidazolylidene ligand is reflected in the $C(1)-R u(1)-C(13)$, $\mathrm{C}(1)-\mathrm{Ru}(1)-\mathrm{Cl}(1)$ and $\mathrm{C}(1)-\mathrm{Ru}(1)-\mathrm{Cl}(2)$ angles of $78.59(12), 92.94(9)$ and $89.64(8)^{\circ}$, respectively, a result that reflects the situation we found in related Ru complexes (Table 2) [52-55]. The atoms comprising the tetramethylbenzyl ring are coplanar, the mean deviation from their least squares plane being $0.017(2) \AA$. The five- and six-membered rings $(\mathrm{N} 1 / \mathrm{C} 1 / \mathrm{N} 2 / \mathrm{C} 7 / \mathrm{C} 2)$ and $(\mathrm{C} 2-\mathrm{C} 7)$ of the benzimidazolylidene group are almost co-planar with maximum deviations of 0.010(2) $\AA$ for N1 and 0.010(2) $\AA$ for C5, respectively. The dihedral angle between benzimidazolylidine and tetramethylbenzyl rings is $84.49(16)^{\circ}$. The Ru-carbene distance, $R u(1)-C(1)$, of 2.040(3) $\AA$, matches the literature data [52-54]. $\mathrm{The} \mathrm{Ru}(1)-\mathrm{Cl}(1)$ and $\mathrm{Ru}(1)-\mathrm{Cl}(2)$ single bond lengths are 2.4267(9) and 2.4222(8) $\AA$. The values of the geometrical parameters of compound $\mathbf{2} \mathbf{b}$ agree with those reported for similar compounds [52-54].

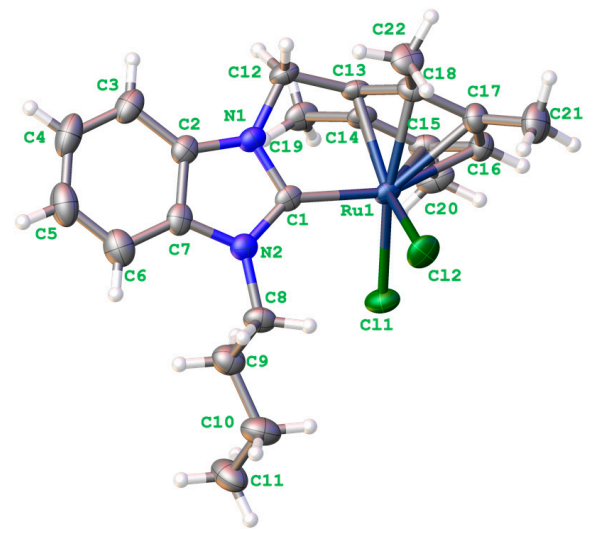

Figure 2. The molecular structure of compound $\mathbf{2 b}$. Displacement ellipsoids are drawn at the $50 \%$ probability level. 
Table 2. Selected bond lengths $(\AA)$, angles $\left(^{\circ}\right)$ and torsion angles $\left(^{\circ}\right)$ for compound $\mathbf{2 b}$.

\begin{tabular}{cccccc}
\hline Bond Lenght & \multicolumn{5}{c}{ Torsion Angle } \\
\hline $\mathrm{C}(1)-\mathrm{N}(2)$ & $1.360(4)$ & $\mathrm{N}(2)-\mathrm{C}(1)-\mathrm{N}(1)$ & $105.2(3)$ & $\mathrm{N}(2)-\mathrm{C}(1)-\mathrm{Ru}(1)-\mathrm{Cl}(2)$ & $-53.0(3)$ \\
$\mathrm{C}(1)-\mathrm{N}(1)$ & $1.361(4)$ & $\mathrm{N}(2)-\mathrm{C}(1)-\mathrm{Ru}(1)$ & $138.3(2)$ & $\mathrm{N}(1)-\mathrm{C}(1)-\mathrm{Ru}(1)-\mathrm{Cl}(2)$ & $129.7(2)$ \\
$\mathrm{C}(1)-\mathrm{Ru}(1)$ & $2.040(3)$ & $\mathrm{N}(1)-\mathrm{C}(1)-\mathrm{Ru}(1)$ & $116.5(2)$ & $\mathrm{N}(2)-\mathrm{C}(1)-\mathrm{Ru}(1)-\mathrm{Cl}(1)$ & $36.1(3)$ \\
$\mathrm{C}(2)-\mathrm{N}(1)$ & $1.386(4)$ & $\mathrm{N}(1)-\mathrm{C}(12)-\mathrm{C}(13)$ & $106.3(2)$ & $\mathrm{N}(1)-\mathrm{C}(1)-\mathrm{Ru}(1)-\mathrm{Cl}(1)$ & $-141.1(2)$ \\
$\mathrm{C}(2)-\mathrm{C}(7)$ & $1.394(5)$ & $\mathrm{C}(14)-\mathrm{C}(13)-\mathrm{Ru}(1)$ & $73.54(17)$ & $\mathrm{N}(2)-\mathrm{C}(1)-\mathrm{N}(1)-\mathrm{C}(12)$ & $176.2(3)$ \\
$\mathrm{C}(7)-\mathrm{N}(2)$ & $1.393(4)$ & $\mathrm{C}(18)-\mathrm{C}(13)-\mathrm{Ru}(1)$ & $73.77(18)$ & $\mathrm{Ru}(1)-\mathrm{C}(1)-\mathrm{N}(1)-\mathrm{C}(2)$ & $177.82(19)$ \\
$\mathrm{C}(8)-\mathrm{N}(2)$ & $1.466(4)$ & $\mathrm{C}(12)-\mathrm{C}(13)-\mathrm{Ru}(1)$ & $116.3(2)$ & & \\
$\mathrm{C}(12)-\mathrm{N}(1)$ & $1.466(4)$ & $\mathrm{C}(1)-\mathrm{N}(1)-\mathrm{C}(2)$ & $111.6(3)$ & & \\
$\mathrm{C}(12)-\mathrm{C}(13)$ & $1.517(4)$ & $\mathrm{C}(1)-\mathrm{N}(1)-\mathrm{C}(12)$ & $121.5(3)$ & & \\
$\mathrm{C}(13)-\mathrm{Ru}(1)$ & $2.109(3)$ & $\mathrm{C}(2)-\mathrm{N}(1)-\mathrm{C}(12)$ & $126.7(3)$ & & \\
$\mathrm{C}(14)-\mathrm{Ru}(1)$ & $2.190(3)$ & $\mathrm{C}(1)-\mathrm{N}(2)-\mathrm{C}(7)$ & $111.1(3)$ & & \\
$\mathrm{C}(15)-\mathrm{C}(16)$ & $1.426(5)$ & $\mathrm{C}(1)-\mathrm{N}(2)-\mathrm{C}(8)$ & $124.5(3)$ & & \\
$\mathrm{C}(15)-\mathrm{C}(20)$ & $1.513(4)$ & $\mathrm{C}(7)-\mathrm{N}(2)-\mathrm{C}(8)$ & $124.3(3)$ & & \\
$\mathrm{C}(15)-\mathrm{Ru}(1)$ & $2.241(3)$ & - & & & \\
$\mathrm{C}(16)-\mathrm{Ru}(1)$ & $2.274(3)$ & - & & & \\
$\mathrm{C}(17)-\mathrm{Ru}(1)$ & $2.267(3)$ & - & & & \\
$\mathrm{C}(18)-\mathrm{Ru}(1)$ & $2.196(3)$ & - & & & \\
$\mathrm{Cl}(1)-\mathrm{Ru}(1)$ & $2.4267(9)$ & - & & & \\
$\mathrm{Cl}(2)-\mathrm{Ru}(1)$ & $2.4222(8)$ & - & & & \\
\hline
\end{tabular}

2.4. Optimization Conditions of Direct Arylation of 2-Phenylpyridine with (hetero)Aryl Chlorides with Catalysts 2

The catalytic activity of the $\left[\mathrm{RuCl}_{2}\left(\eta^{6}, \eta^{1}-1\right.\right.$-arylmethyl-3-butylbenzimidazole-2-ylidene)] complexes $\mathbf{2 a}-\mathbf{e}$ for the activation of phenylpyridine towards (hetero)arylation of $\mathrm{sp}^{2} \mathrm{C}-\mathrm{H}$ bonds was investigated by the reaction of (hetero)aryl chloride and 2-phenylpyridine as a standard reaction. The reaction was carried out using 2-phenylpyridine, (hetero)aryl chloride and $\mathrm{Cs}_{2} \mathrm{CO}_{3}$ in the presence of complex $2 \mathrm{c}$ as the catalyst in water with $\mathrm{Cs}_{2} \mathrm{CO}_{3}$ as a base and a carboxylate $\mathrm{RCO}_{2} \mathrm{~K}$ as additive. The results of varying the reaction parameters, including base, additive and reaction time are given in Table 3.

It has been shown by Dixneuf's group [43-49] that carboxylates were efficient partners for ruthenium(II) C-H bond activation at room temperature, especially in water [44] The mechanism of the catalytic cycle showed that a carboxylate was crucial to deprotonate the $\mathrm{C}-\mathrm{H}$ bond of aromatic systems [48,49]. Thus, pivalate and acetate additives were evaluated. When KOPiv was used as additive, the reaction gave low conversion of only $9 \%$ with $\mathrm{Cs}_{2} \mathrm{CO}_{3}$ after $5 \mathrm{~h}$ at $100{ }^{\circ} \mathrm{C}$, and $100 \%$ (Table 3, entry 1). However, when $\mathrm{K}_{2} \mathrm{CO}_{3}$ and $\mathrm{Na}_{2} \mathrm{CO}_{3}$ were used as bases under similar conditions, no reaction took place (Table 3, entries 2 and 3). In the presence of KOAc as additive, the conversion was increased to $15 \%$ with $\mathrm{Cs}_{2} \mathrm{CO}_{3}$ after $5 \mathrm{~h}$ at $100{ }^{\circ} \mathrm{C}$, to give mono-alkylated product, $\mathrm{A}$, was also observed (Table 3, entry 4). When the reaction time was increased from $5 \mathrm{~h}$ to $10 \mathrm{~h}$, the conversion was improved to $47 \%$ and $100 \%$ yield (Table 3, entry 5). Similarly, when the reaction time was increased from 10 to $20 \mathrm{~h}$, the conversion was improved to $95 \%$ and $100 \%$ yield of product A was also observed (Table 2 , entry 6). However, when the reaction time was increased from 20 to $24 \mathrm{~h}$, no significant difference was observed in the conversion (Table 3, entry 7). These conditions (Table 3, entry 6) were selected for mono ortho-heteroarylation of phenylpyridine. As a result, the scope of the direct arylation of 2-phenylpyridine was investigated with 2-chlorothiophene applying our best experimental conditions (Table 3, entry 6). When 4-chlorotoluene was used as model coupling partner, the reaction gave full conversion (100\% yield of mono-alkylated product $\mathrm{A}$, was observed) with $\mathrm{Cs}_{2} \mathrm{CO}_{3}$ as base at different durations (5-20 h) at $100{ }^{\circ} \mathrm{C}$ (Table 3, entries 8-10). Eventually, the scope of the direct arylation of 2-phenylpyridine was investigated with 4-chlorotoluene applying our best experimental conditions (Table 3, entry 10). This shows that ortho-arylation is much easier than heteroarylation. 
Table 3. Arylation of 2-phenylpyridine with (hetero)aryl chlorides: A search for optimal catalytic conditions ${ }^{\text {a }}$.

i) Catalyst $\mathbf{2 c}(2.5 \mathrm{~mol} \%)$
ii) $\mathrm{RCO}_{2} \mathrm{~K}$ additive $(5 \mathrm{~mol} \%)$

a Reaction conditions: Additive (0.05 mmol), ruthenium(II)-NHC complex, $2 \mathrm{c}(0.025 \mathrm{mmol}), \mathrm{H}_{2} \mathrm{O}$ as solvent $(2 \mathrm{~mL})$, r.t. for $1 \mathrm{~h}$, then 2-phenylpyridine $(0.5 \mathrm{mmol})$, (hetero)aryl chloride $(1.25 \mathrm{mmol})$, base $(1.5 \mathrm{mmol})$. The conversions were based on the 2-phenylpyridine by GC (Gas chromatography) and GC-MS (Gas chromatography-Mass Spectrometry).

\subsection{Direct Arylation of 2-Phenylpyridine with (Hetero)Aryl Chlorides}

Based on this preliminary study, the scope of the direct arylation of 2-phenylpyridine was investigated with various (hetero)aryl chlorides applying our best experimental conditions to produce new potential bidentate ligands. With $\mathrm{KOAc}$ as additive, $\mathrm{Cs}_{2} \mathrm{CO}_{3}$ as base in water at $100{ }^{\circ} \mathrm{C}$ for different durations, ruthenium complexes $\mathbf{2 a - e}$ were examined in the direct arylations of 2-phenylpyridine with six aryl chloride and thiophenyl chloride. In all of the reactions between different (hetero)aryl chlorides and 2-phenylpyridine, mono ortho-arylated product (A) was formed selectively. In addition, high conversion of ortho-arylated products was observed, and the selectivity was in high ratio towards to A. Although the other aryl chlorides showed good conversion in $5 \mathrm{~h}$, chlorobenzene showed full conversion after 1 h. For example, when $\mathbf{2 a}$ and $\mathbf{2} \mathbf{b}$ complexes were used as catalyst, ortho-arylated product observed full conversion (selectivity of A 100\%), (Table 4, entries 1 and 2). When the reaction of 2-phenylpyridine with 4-chlorotoluene was performed by compounds $\mathbf{2 a}, \mathbf{2 b}$ and 2c, ortho-arylated products (A and B) obtained full conversion (selectivity of A 100\%), (Table 4, entries 6-8). When the reaction of 2-phenylpyridine with 4-chlorobenzaldehyde was performed by compounds 2a-e, ortho-arylated products (A and B) obtained full conversion (Table 4, entries 11-15). When compound $2 \mathbf{e}$ was used as catalyst, high conversion $(>80 \%)$ was observed (selectivity of $\mathrm{A}>85 \%$ ) (Table 4, entries 20 and 30). Heteroaryl derivative such as 2-chlorothiophene was also applicable to this direct arylation system (Table 4, entries 31-35). When compound 2c was used as catalyst, ortho-arylated product was observed in conversion of 95\% (selectivity of A 100\%), (Table 4, entry 33). These results show that catalysts $\mathbf{2 a}-\mathbf{2} \mathbf{b}$ were the best for monoarylation with simple phenyl and tolyl chlorides. For functional aryl chlorides $\mathrm{ClC}_{6} \mathrm{H}_{4} \mathrm{Y}, \mathbf{2 d}(\mathrm{Y}=\mathrm{CHO}), \mathbf{2 e}(\mathrm{Y}=\mathrm{COMe}$ and $\mathrm{Y}=\mathrm{CN}), \mathbf{2 c}$ (thiophenyl chloride) appeared the most efficient. 
Table 4. Direct arylation of 2-phenylpyridine with (hetero)aryl chlorides catalyzed by ruthenium(II)-NHC complexes $\mathbf{2} \mathbf{a}-\mathbf{e}^{\mathrm{a}}$.

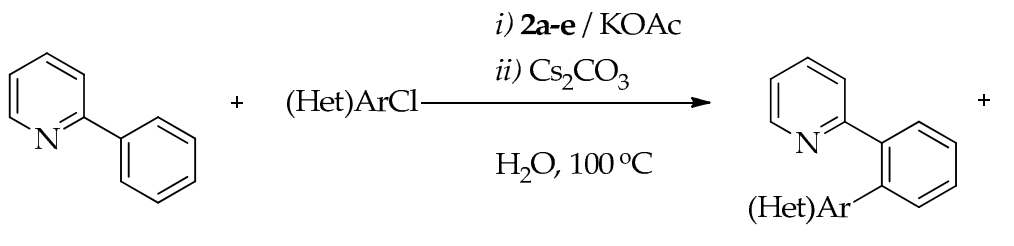

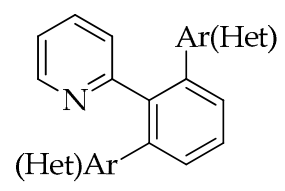

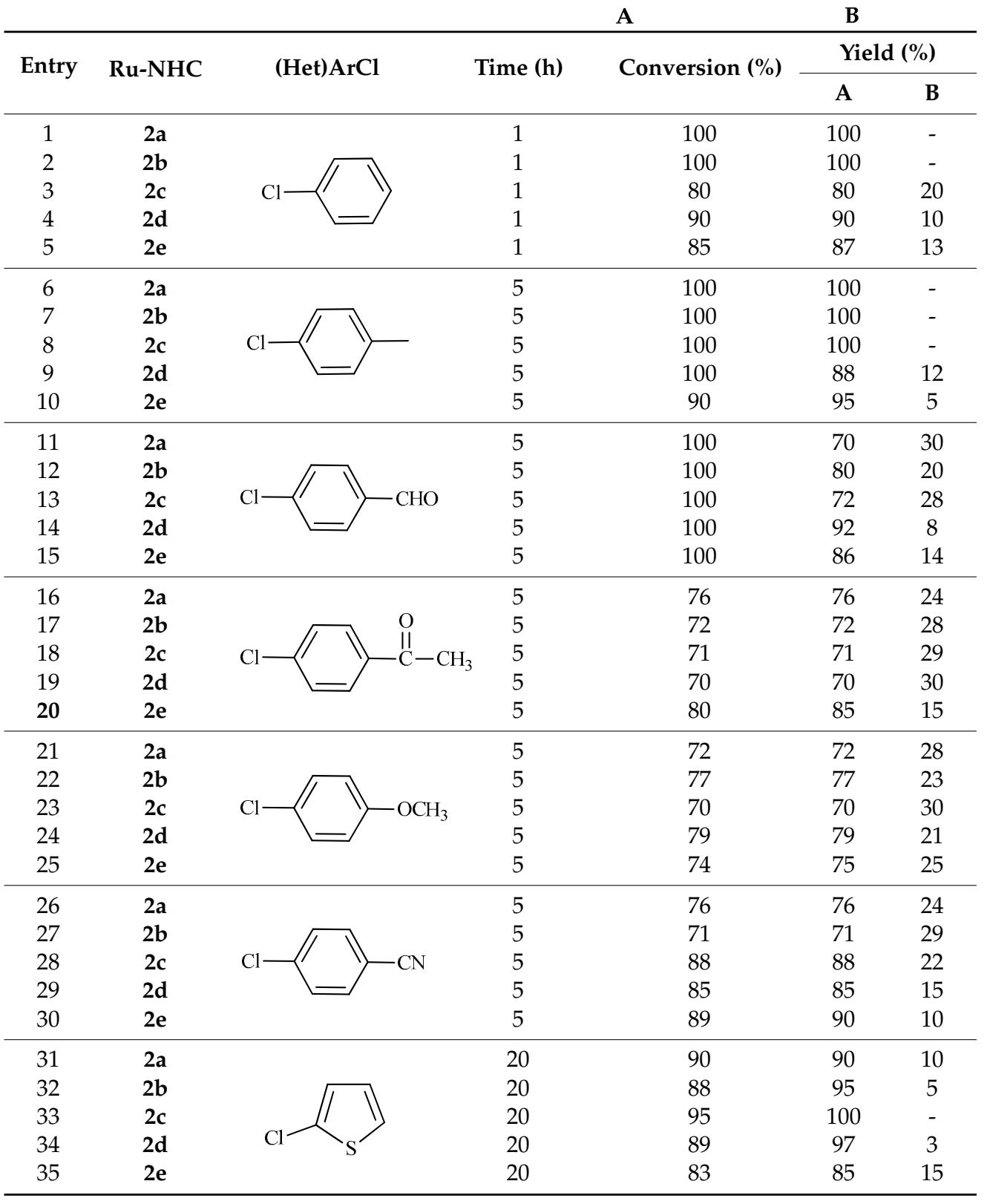

${ }^{a}$ Reaction conditions: KOAc $(0.05 \mathrm{mmol})$, ruthenium(II)-NHC complexes $\mathbf{2 a}-\mathbf{e}(0.025 \mathrm{mmol}), \mathrm{H}_{2} \mathrm{O}$ as solvent $(2 \mathrm{~mL})$, r.t. for $1 \mathrm{~h}$, then 2-phenylpyridine $(0.5 \mathrm{mmol})$, ( $\mathrm{Het}) \mathrm{ArCl}(1.25 \mathrm{mmol}), \mathrm{Cs}_{2} \mathrm{CO}_{3}(1.5 \mathrm{mmol})$. 


\section{Materials and Methods}

\subsection{General}

All reactions for the preparation benzimidazolium halides (1a-e) and (arene)ruthenium(II)-(NHC)(Cl) 2 complexes $(\mathbf{2 a}-\mathbf{e})$ were carried out under argon in flame-dried glassware using standard Schlenk techniques. Chemicals and solvents were purchased from Sigma-Aldrich (Istanbul, Turkey) and Merck (Istanbul, Turkey). The solvents used were purified by distillation over the drying agents indicated and were transferred under Argon, $\mathrm{Et}_{2} \mathrm{O}\left(\mathrm{Na} / \mathrm{K}\right.$ alloy), $\mathrm{CH}_{2} \mathrm{Cl}_{2}\left(\mathrm{P}_{4} \mathrm{O}_{10}\right)$, hexane, and toluene (Na). Microanalyses were performed by İnönü University Scientific and Technological Research Center (Malatya, Turkey). Melting points were determined in glass capillaries under air with an Electrothermal-9200 melting point apparatus (Cole-Parmer, Istanbul, Turkey). FT-IR spectra were recorded on ATR (Attenuated Total Reflection) unit in the range of 400-4000 $\mathrm{cm}^{-1}$ with Perkin Elmer Spectrum 100 Spectrophotometer (Istanbul, Turkey). Routine ${ }^{1} \mathrm{H}$ NMR and ${ }^{13} \mathrm{C}$ NMR spectra were recorded using a Bruker Avance AMX spectrometer (Ankara, Turkey) operating at 300 and $400 \mathrm{MHz}$ for ${ }^{1} \mathrm{H} \mathrm{NMR}$, and at 75 and $100 \mathrm{MHz}$ for ${ }^{13} \mathrm{C} \mathrm{NMR}$ in $\mathrm{CDCl}_{3}$ with tetramethylsilane as an internal reference. Chemical shifts $(\delta)$ and coupling constants $(J)$ are reported in ppm and in $\mathrm{Hz}$, respectively. ${ }^{1} \mathrm{H} \mathrm{NMR}$ spectra are referenced to $\mathrm{CDCl}_{3}\left(\delta=7.26 \mathrm{ppm}\right.$ for $\left.\mathrm{CDCl}_{3}\right),{ }^{13} \mathrm{C}$ chemical shifts are reported relative to deuteriated solvent $\left(\delta=77.16 \mathrm{ppm}\right.$ for $\left.\mathrm{CDCl}_{3}\right)$. All catalytic reactions were monitored on an Agilent 6890N Gas Chromatography (Ankara, Turkey) and Schimadzu 2010 Plus GC-MS system (Ankara, Turkey) by GC-FID (Flame Ionization Dedector) with a HP-5 column of $30 \mathrm{~m}$ length, $0.32 \mathrm{~mm}$ diameter and $0.25 \mu \mathrm{m}$ film thickness. Column chromatography was performed using silica gel 60 (70-230 mesh).

\subsection{General Procedure for the Preparation of Benzimidazolium Halides 1a-e}

To a solution of 1-( $n$-butyl)benzimidazole $(5.0 \mathrm{mmol})$ in DMF $(5 \mathrm{~mL})$ was added benzyl halide $(5.0 \mathrm{mmol})$ and the resulting mixture was stirred at $80{ }^{\circ} \mathrm{C}$ for $5 \mathrm{~h}$. After completion of the reaction, the solvent was removed by vacuum and diethylether $(15 \mathrm{~mL})$ was added to obtain a white crystalline solid, which was filtered off. The solid was washed with diethyl ether $(3 \times 10 \mathrm{~mL})$ and dried under vacuum. The crude product was recrystallized from EtOH/Et ${ }_{2} \mathrm{O}$ mixture $(1: 2, v / v)$ and dried under vacuum. The ${ }^{1} \mathrm{H}$ NMR and ${ }^{13} \mathrm{C}$ NMR spectrums of new benzimidazolium halides $(\mathbf{1 a}, \mathbf{1 b}, \mathbf{1 d}$ and $\mathbf{1 e})$ are available supporting information (Figures S1-S4).

1-(3-Methylbenzyl)-3-(n-Butyl)Benzimidazolium Chloride, 1a: $\left(1.228 \mathrm{~g}\right.$, yield 78\%) ${ }^{1} \mathrm{H} \mathrm{NMR}(400 \mathrm{MHz}$, $\left.\mathrm{CDCl}_{3}, 25{ }^{\circ} \mathrm{C}\right): \delta=0.90\left(\mathrm{t},{ }^{3} \mathrm{~J}=7.4 \mathrm{~Hz}, 3 \mathrm{H}, \mathrm{CH}_{2} \mathrm{CH}_{2} \mathrm{CH}_{2} \mathrm{CH}_{3}\right) ; 1.38$ (hext, ${ }^{3} \mathrm{~J}=7.5 \mathrm{~Hz}, 2 \mathrm{H}$, $\mathrm{CH}_{2} \mathrm{CH}_{2} \mathrm{CH}_{2} \mathrm{CH}_{3}$ ); 1.97 (pent, ${ }^{3} \mathrm{~J}=7.5 \mathrm{~Hz}, 2 \mathrm{H}, \mathrm{CH}_{2} \mathrm{CH}_{2} \mathrm{CH}_{2} \mathrm{CH}_{3}$ ); 2.22 (s, 3H, $\mathrm{CH}_{2} \mathrm{C}_{6} \mathrm{H}_{4}\left(\mathrm{CH}_{3}\right)-3$ ); $4.57\left(\mathrm{t},{ }^{3} \mathrm{~J}=7.4 \mathrm{~Hz}, 2 \mathrm{H}, \mathrm{CH}_{2} \mathrm{CH}_{2} \mathrm{CH}_{2} \mathrm{CH}_{3}\right) ; 5.79$ (s, 2H, $\left.\mathrm{CH}_{2} \mathrm{C}_{6} \mathrm{H}_{4}\left(\mathrm{CH}_{3}\right)-3\right) ; 7.04\left(\mathrm{~d},{ }^{3} \mathrm{~J}=7.5 \mathrm{~Hz}, 1 \mathrm{H}\right.$, arom. $\mathrm{CH}, \mathrm{NC}_{6} \mathrm{H}_{4} \mathrm{~N}$ and $\left.\mathrm{CH}_{2} \mathrm{C}_{6} \mathrm{H}_{4}\left(\mathrm{CH}_{3}\right)-3\right) ; 7.13-7.21$ (m, 3H, arom. $\mathrm{CH}, \mathrm{NC}_{6} \mathrm{H}_{4} \mathrm{~N}$ and $\left.\mathrm{CH}_{2} \mathrm{C}_{6} \mathrm{H}_{4}\left(\mathrm{CH}_{3}\right)-3\right)$; 7.47-7.57 (m, 3H, arom. $\mathrm{CH}, \mathrm{NC}_{6} \mathrm{H}_{4} \mathrm{~N}$ and $\left.\mathrm{CH}_{2} \mathrm{C}_{6} \mathrm{H}_{4}\left(\mathrm{CH}_{3}\right)-3\right) ; 7.67\left(\mathrm{~d},{ }^{3} \mathrm{~J}=8.2 \mathrm{~Hz}, 1 \mathrm{H}\right.$, arom. $\mathrm{CH}$, $\mathrm{NC}_{6} \mathrm{H}_{4} \mathrm{~N}$ and $\left.\mathrm{CH}_{2} \mathrm{C}_{6} \mathrm{H}_{4}\left(\mathrm{CH}_{3}\right)-3\right) ; 11.49$ (s, 1H, NCHN) ppm. ${ }^{13} \mathrm{C} \mathrm{NMR}\left(100 \mathrm{MHz}, \mathrm{CDCl}_{3}, 25{ }^{\circ} \mathrm{C}\right)$ : $\delta=13.5\left(\mathrm{CH}_{2} \mathrm{CH}_{2} \mathrm{CH}_{2} \mathrm{CH}_{3}\right) ; 19.8\left(\mathrm{CH}_{2} \mathrm{CH}_{2} \mathrm{CH}_{2} \mathrm{CH}_{3}\right) ; 21.3\left(\mathrm{CH}_{2} \mathrm{C}_{6} \mathrm{H}_{4}\left(\mathrm{CH}_{3}\right)-3\right) ; 31.3\left(\mathrm{CH}_{2} \mathrm{CH}_{2} \mathrm{CH}_{2} \mathrm{CH}_{3}\right)$; $47.5\left(\mathrm{CH}_{2} \mathrm{CH}_{2} \mathrm{CH}_{2} \mathrm{CH}_{3}\right) ; 51.3\left(\mathrm{CH}_{2} \mathrm{C}_{6} \mathrm{H}_{4}\left(\mathrm{CH}_{3}\right)-3\right) ; 113.1,113.9,125.3,127.0,127.1,128.8,129.1,129.8$, 131.2, 131.5, 132.9, 139.1 (arom. $C, \mathrm{NC}_{6} \mathrm{H}_{4} \mathrm{~N}$ and $\mathrm{CH}_{2} \mathrm{C}_{6} \mathrm{H}_{4}\left(\mathrm{CH}_{3}\right)-3$ ); 143.2 (NCHN) ppm (Figure S1). Elemental analysis calcd (\%) for $\mathrm{C}_{19} \mathrm{H}_{23} \mathrm{ClN}_{2}$ (Molar Mass (Mr) = 314.90): C 72.48, H 7.36, N 8.90; found (\%): C 72.54, H 7.38, N 8.93.

1-(2,3,5,6-Tetramethylbenzyl)-3-(n-Butyl)Benzimidazolium Chloride, 1b: (1.481 g, yield 83\%) ${ }^{1} \mathrm{H}$ NMR $\left(300 \mathrm{MHz}, \mathrm{CDCl}_{3}, 25^{\circ} \mathrm{C}\right): \delta=0.87\left(\mathrm{t},{ }^{3} \mathrm{~J}=7.0 \mathrm{~Hz}, 3 \mathrm{H}, \mathrm{CH}_{2} \mathrm{CH}_{2} \mathrm{CH}_{2} \mathrm{CH}_{3}\right) ; 1.33$ (hext, ${ }^{3} \mathrm{~J}=6.9 \mathrm{~Hz}, 2 \mathrm{H}$, $\mathrm{CH}_{2} \mathrm{CH}_{2} \mathrm{CH}_{2} \mathrm{CH}_{3}$ ); 1.91 (pent, $\left.{ }^{3} \mathrm{~J}=6.5 \mathrm{~Hz}, 2 \mathrm{H}, \mathrm{CH}_{2} \mathrm{CH}_{2} \mathrm{CH}_{2} \mathrm{CH}_{3}\right) ; 2.16$ (s, $\left.12 \mathrm{H}, \mathrm{CH}_{2} \mathrm{C}_{6} \mathrm{H}\left(\mathrm{CH}_{3}\right)_{4}-2,3,5,6\right)$; $4.61\left(\mathrm{t},{ }^{3} \mathrm{~J}=6.3 \mathrm{~Hz}, 2 \mathrm{H}, \mathrm{CH}_{2} \mathrm{CH}_{2} \mathrm{CH}_{2} \mathrm{CH}_{3}\right) ; 5.85\left(\mathrm{~s}, 2 \mathrm{H}, \mathrm{CH}_{2} \mathrm{C}_{6} \mathrm{H}\left(\mathrm{CH}_{3}\right)_{4}-2,3,5,6\right) ; 6.98$ (s, 1H, arom. $\mathrm{CH}$, $\left.\mathrm{CH}_{2} \mathrm{C}_{6} \mathrm{H}\left(\mathrm{CH}_{3}\right)_{4}-2,3,5,6\right) ; 7.22\left(\mathrm{~d},{ }^{3} \mathrm{~J}=8.2 \mathrm{~Hz}, 1 \mathrm{H}\right.$, arom. $\mathrm{CH}$ of benzimidazole, $\left.\mathrm{NC}_{6} \mathrm{H}_{4} \mathrm{~N}\right) ; 7.40(\mathrm{t}$, ${ }^{3} \mathrm{~J}=7.7 \mathrm{~Hz}, 1 \mathrm{H}$, arom. $\mathrm{CH}$ of benzimidazole, $\left.\mathrm{NC}_{6} \mathrm{H}_{4} \mathrm{~N}\right) ; 7.53\left(\mathrm{t},{ }^{3} \mathrm{~J}=7.4 \mathrm{~Hz}, 1 \mathrm{H}\right.$, arom. $\mathrm{CH}$ 
of benzimidazole, $\left.\mathrm{NC}_{6} \mathrm{H}_{4} \mathrm{~N}\right) ; 7.69\left(\mathrm{~d},{ }^{3} \mathrm{~J}=8.0 \mathrm{~Hz}, 1 \mathrm{H}\right.$, arom. $\mathrm{CH}$ of benzimidazole, $\left.\mathrm{NC}_{6} \mathrm{H}_{4} \mathrm{~N}\right)$; $10.86(\mathrm{~s}, 1 \mathrm{H}, \mathrm{NCHN})$ ppm. ${ }^{13} \mathrm{C} \mathrm{NMR}\left(75 \mathrm{MHz}, \mathrm{CDCl}_{3}, 25{ }^{\circ} \mathrm{C}\right): \delta=13.5\left(\mathrm{CH}_{2} \mathrm{CH}_{2} \mathrm{CH}_{2} \mathrm{CH}_{3}\right)$; $16.0 \quad\left(\mathrm{CH}_{2} \mathrm{C}_{6} \mathrm{H}\left(\mathrm{CH}_{3}\right)_{4}-2,3,5,6\right) ; \quad 19.7 \quad\left(\mathrm{CH}_{2} \mathrm{CH}_{2} \mathrm{CH}_{2} \mathrm{CH}_{3}\right) ; \quad 20.5 \quad\left(\mathrm{CH}_{2} \mathrm{C}_{6} \mathrm{H}\left(\mathrm{CH}_{3}\right)_{4}-2,3,5,6\right) ; \quad 31.3$ $\left(\mathrm{CH}_{2} \mathrm{CH}_{2} \mathrm{CH}_{2} \mathrm{CH}_{3}\right) ; 47.5\left(\mathrm{CH}_{2} \mathrm{CH}_{2} \mathrm{CH}_{2} \mathrm{CH}_{3}\right) ; 47.8\left(\mathrm{CH}_{2} \mathrm{C}_{6} \mathrm{H}\left(\mathrm{CH}_{3}\right)_{4}-2,3,5,6\right) ; 113.1,113.8,127.0,127.2$, 127.9, 131.4, 131.5, 133.4, 134.0, 134.9 (arom. $C, \mathrm{NC}_{6} \mathrm{H}_{4} \mathrm{~N}$ and $\left.\mathrm{CH}_{2} \mathrm{C}_{6} \mathrm{H}\left(\mathrm{CH}_{3}\right)_{4}-2,3,5,6\right) ; 142.9$ (NCHN) ppm (Figure S2). Elemental analysis calcd (\%) for $\mathrm{C}_{22} \mathrm{H}_{29} \mathrm{ClN}_{2}(\mathrm{Mr}=356.90)$ : C 74.03, H 8.19, N 7.85; found (\%): C 74.00, H 8.16, N 7.81.

1-(4-tert-Butylbenzyl)-3-(n-Butyl)Benzimidazolium Bromide, 1d: (1.605 g, yield 80\%) ${ }^{1} \mathrm{H}$ NMR $(400 \mathrm{MHz}$,

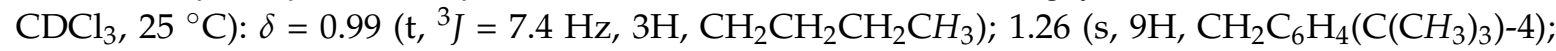
1.48 (hext, ${ }^{3} \mathrm{~J}=7.7 \mathrm{~Hz}, 2 \mathrm{H}, \mathrm{CH}_{2} \mathrm{CH}_{2} \mathrm{CH}_{2} \mathrm{CH}_{3}$ ); 2.07 (pent, ${ }^{3} \mathrm{~J}=7.6 \mathrm{~Hz}, 2 \mathrm{H}, \mathrm{CH}_{2} \mathrm{CH}_{2} \mathrm{CH}_{2} \mathrm{CH}_{3}$ );

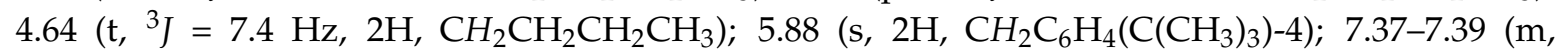

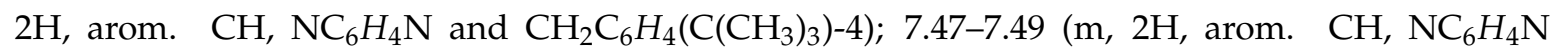

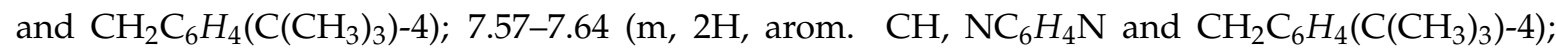

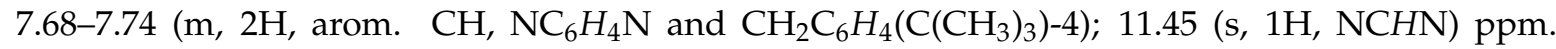
${ }^{13} \mathrm{C}$ NMR $\left(100 \mathrm{MHz}, \mathrm{CDCl}_{3}, 25{ }^{\circ} \mathrm{C}\right): \delta=13.5\left(\mathrm{CH}_{2} \mathrm{CH}_{2} \mathrm{CH}_{2} \mathrm{CH}_{3}\right) ; 19.9\left(\mathrm{CH}_{2} \mathrm{CH}_{2} \mathrm{CH}_{2} \mathrm{CH}_{3}\right) ; 31.2$ $\left(\mathrm{CH}_{2} \mathrm{C}_{6} \mathrm{H}_{4}\left(\mathrm{C}\left(\mathrm{CH}_{3}\right)_{3}\right)-4\right) ; 31.3\left(\mathrm{CH}_{2} \mathrm{CH}_{2} \mathrm{CH}_{2} \mathrm{CH}_{3}\right) ; 34.7\left(\mathrm{CH}_{2} \mathrm{C}_{6} \mathrm{H}_{4}\left(\mathrm{C}\left(\mathrm{CH}_{3}\right)_{3}\right)-4\right) ; 47.6\left(\mathrm{CH}_{2} \mathrm{CH}_{2} \mathrm{CH}_{2} \mathrm{CH}_{3}\right)$;

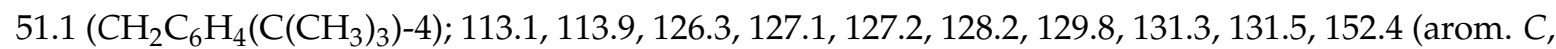

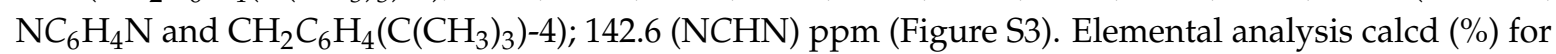
$\mathrm{C}_{22} \mathrm{H}_{29} \mathrm{BrN}_{2}(\mathrm{Mr}=401.40):$ C 65.83, H 7.28, N 6.98; found (\%): C 65.75, H 7.29, N 6.95.

1-(2,3,5,6-Tetramethylbenzyl)-3-(3-Methoxybenzyl)Benzimidazolium Chloride, 1e: $(1.831 \mathrm{~g}$, yield $87 \%){ }^{1} \mathrm{H}$ NMR (300 MHz, $\left.\mathrm{CDCl}_{3}, 25{ }^{\circ} \mathrm{C}\right): \delta=2.25$ and $2.26\left(\mathrm{~s}, 12 \mathrm{H}, \mathrm{CH}_{2} \mathrm{C}_{6} \mathrm{H}\left(\mathrm{CH}_{3}\right)_{4}-2,3,5,6\right) ; 3.76(\mathrm{~s}, 3 \mathrm{H}$, $\left.\mathrm{CH}_{2} \mathrm{C}_{6} \mathrm{H}_{4}\left(\mathrm{OCH}_{3}\right)-4\right) ; 5.88$ (s, $\left.2 \mathrm{H}, \mathrm{CH}_{2} \mathrm{C}_{6} \mathrm{H}_{4}\left(\mathrm{OCH}_{3}\right)-4\right) ; 5.89$ (s, $\left.2 \mathrm{H}, \mathrm{CH}_{2} \mathrm{C}_{6} \mathrm{H}\left(\mathrm{CH}_{3}\right)_{4}-2,3,5,6\right) ; 6.86$ $\left(\mathrm{d},{ }^{3} \mathrm{~J}=8.6 \mathrm{~Hz}, 2 \mathrm{H}\right.$, arom. $\mathrm{CH}, \mathrm{NC}_{6} \mathrm{H}_{4} \mathrm{~N}$ and $\left.\mathrm{CH}_{2} \mathrm{C}_{6} \mathrm{H}_{4}\left(\mathrm{OCH}_{3}\right)-4\right) ; 7.08$ (s, $1 \mathrm{H}$, arom. $\mathrm{CH}$, $\left.\mathrm{CH}_{2} \mathrm{C}_{6} \mathrm{H}\left(\mathrm{CH}_{3}\right)_{4}-2,3,5,6\right) ; 7.20\left(\mathrm{~d},{ }^{3} \mathrm{~J}=8.1 \mathrm{~Hz}, 1 \mathrm{H}\right.$, arom. $\mathrm{CH}, \mathrm{NC}_{6} \mathrm{H}_{4} \mathrm{~N}$ and $\left.\mathrm{CH}_{2} \mathrm{C}_{6} \mathrm{H}_{4}\left(\mathrm{OCH}_{3}\right)-4\right)$; 7.38-7.51 (m, $4 \mathrm{H}$, arom. $\mathrm{CH}, \mathrm{NC}_{6} \mathrm{H}_{4} \mathrm{~N}$ and $\left.\mathrm{CH}_{2} \mathrm{C}_{6} \mathrm{H}_{4}\left(\mathrm{OCH}_{3}\right)-4\right) ; 7.61\left(\mathrm{~d},{ }^{3} \mathrm{~J}=8.1 \mathrm{~Hz}, 1 \mathrm{H}\right.$, arom. $\mathrm{CH}$, $\mathrm{NC}_{6} \mathrm{H}_{4} \mathrm{~N}$ and $\left.\mathrm{CH}_{2} \mathrm{C}_{6} \mathrm{H}_{4}\left(\mathrm{OCH}_{3}\right)-4\right) ; 11.53$ (s, $\left.1 \mathrm{H}, \mathrm{NCHN}\right)$ ppm. ${ }^{13} \mathrm{C} \mathrm{NMR}\left(75 \mathrm{MHz}, \mathrm{CDCl}_{3}, 25{ }^{\circ} \mathrm{C}\right.$ ): $\delta=16.2$ and $20.6\left(\mathrm{CH}_{2} \mathrm{C}_{6} \mathrm{H}\left(\mathrm{CH}_{3}\right)_{4}-2,3,5,6\right) ; 47.9\left(\mathrm{CH}_{2} \mathrm{C}_{6} \mathrm{H}\left(\mathrm{CH}_{3}\right)_{4}-2,3,5,6\right) ; 51.1\left(\mathrm{CH}_{2} \mathrm{C}_{6} \mathrm{H}_{4}\left(\mathrm{OCH}_{3}\right)-4\right)$; $55.3\left(\mathrm{CH}_{2} \mathrm{C}_{6} \mathrm{H}_{4}\left(\mathrm{OCH}_{3}\right)-4\right) ; 113.6,113.8,114.6,114.7,125.1,126.9,127.0,127.7,129.9,131.6,133.6,134.1$, 135.1, 160.1 (arom. C, $\mathrm{NC}_{6} \mathrm{H}_{4} \mathrm{~N}, \mathrm{CH}_{2} \mathrm{C}_{6} \mathrm{H}\left(\mathrm{CH}_{3}\right)_{4}-2,3,5,6$ and $\left.\mathrm{CH}_{2} \mathrm{C}_{6} \mathrm{H}_{4}\left(\mathrm{OCH}_{3}\right)-4\right) ; 143.6$ (NCHN) ppm (Figure S4). Elemental analysis calcd (\%) for $\mathrm{C}_{26} \mathrm{H}_{29} \mathrm{ClN}_{2} \mathrm{O}(\mathrm{Mr}=421.00)$ : C 74.18, H 6.94, N 6.65; found (\%): C 74.24, H 6.96, N 6.67.

\subsection{General Procedure for the Preparation of Ruthenium(II)NHC Complexes $\mathbf{2 a - e}$}

A suspension of the benzimidazolium halide $(1.10 \mathrm{mmol}), \mathrm{Cs}_{2} \mathrm{CO}_{3}(1.10 \mathrm{mmol})$ and $\left[\mathrm{RuCl}_{2}(p \text {-cymene })\right]_{2}(0.50 \mathrm{mmol})$ in degassed toluene $(20 \mathrm{~mL})$ was heated under reflux for $5 \mathrm{~h}$. The reaction mixture was then filtered while hot, and the volume was reduced to about $10 \mathrm{~mL}$ before the addition of $n$-hexane $(15 \mathrm{~mL})$. The precipitate formed was crystallized from $\mathrm{CH}_{2} \mathrm{Cl}_{2} /$ hexane mixture $(1: 3, v / v)$ to give red-brown crystals. The ${ }^{1} \mathrm{H}$ NMR and ${ }^{13} \mathrm{C}$ NMR spectrums of new ruthenium(II)-NHC complexes (2a-e) are available supporting information (Figures S5-S9).

Dichloro-[1-(3-methylbenzyl)-3-(n-butyl)Benzimidazol-2-ylidene]ruthenium(II), 2a: $\left(0.391 \mathrm{~g}\right.$, yield 87\%) ${ }^{1} \mathrm{H}$ $\operatorname{NMR}\left(300 \mathrm{MHz}, \mathrm{CDCl}_{3}, 25^{\circ} \mathrm{C}\right): \delta=0.95\left(\mathrm{t},{ }^{3} \mathrm{~J}=7.4 \mathrm{~Hz}, 3 \mathrm{H}, \mathrm{CH}_{2} \mathrm{CH}_{2} \mathrm{CH}_{2} \mathrm{CH}_{3}\right) ; 1.45$ (hext, ${ }^{3} \mathrm{~J}=7.6 \mathrm{~Hz}$, $2 \mathrm{H}, \mathrm{CH}_{2} \mathrm{CH}_{2} \mathrm{CH}_{2} \mathrm{CH}_{3}$ ); 1.87 (pent, $\left.{ }^{3} J=7.8 \mathrm{~Hz}, 2 \mathrm{H}, \mathrm{CH}_{2} \mathrm{CH}_{2} \mathrm{CH}_{2} \mathrm{CH}_{3}\right) ; 2.23$ (s, $3 \mathrm{H}, \mathrm{CH}_{2} \mathrm{C}_{6} \mathrm{H}_{4}\left(\mathrm{CH}_{3}\right)-3$ ); 4.39-4.51 (m, $\left.2 \mathrm{H}, \mathrm{CH}_{2} \mathrm{CH}_{2} \mathrm{CH}_{2} \mathrm{CH}_{3}\right) ; 4.89\left(\mathrm{dd}, J=66.5,11.6 \mathrm{~Hz}, 2 \mathrm{H}, \mathrm{CH}_{2} \mathrm{C}_{6} \mathrm{H}_{4}\left(\mathrm{CH}_{3}\right)-3\right) ; 5.07(\mathrm{~s}, 1 \mathrm{H}$, arom. $\left.\mathrm{CH}, \mathrm{CH}_{2} \mathrm{C}_{6} \mathrm{H}_{4}\left(\mathrm{CH}_{3}\right)-3\right) ; 5.40\left(\mathrm{~d},{ }^{3} \mathrm{~J}=5.6 \mathrm{~Hz}, 1 \mathrm{H}\right.$, arom. $\left.\mathrm{CH}, \mathrm{CH}_{2} \mathrm{C}_{6} \mathrm{H}_{4}\left(\mathrm{CH}_{3}\right)-3\right) ; 5.79\left(\mathrm{~d},{ }^{3} \mathrm{~J}=6.0 \mathrm{~Hz}\right.$, $1 \mathrm{H}$, arom. $\left.\mathrm{CH}, \mathrm{CH}_{2} \mathrm{C}_{6} \mathrm{H}_{4}\left(\mathrm{CH}_{3}\right)-3\right) ; 5.93\left(\mathrm{t},{ }^{3} \mathrm{~J}=5.8 \mathrm{~Hz}, 1 \mathrm{H}\right.$, arom. $\left.\mathrm{CH}, \mathrm{CH}_{2} \mathrm{C}_{6} \mathrm{H}_{4}\left(\mathrm{CH}_{3}\right)-3\right) ; 7.32-7.37(\mathrm{~m}$, $3 \mathrm{H}$, arom. $\mathrm{CH}$ of benzimidazole, $\left.\mathrm{NC}_{6} \mathrm{H}_{4} \mathrm{~N}\right) ; 7.42-7.46\left(\mathrm{~m}, 1 \mathrm{H}\right.$, arom. $\mathrm{CH}$ of benzimidazole, $\left.\mathrm{NC}_{6} \mathrm{H}_{4} \mathrm{~N}\right)$ ppm. ${ }^{13} \mathrm{C} \mathrm{NMR}\left(75 \mathrm{MHz}, \mathrm{CDCl}_{3}, 25^{\circ} \mathrm{C}\right): \delta=13.9\left(\mathrm{CH}_{2} \mathrm{CH}_{2} \mathrm{CH}_{2} \mathrm{CH}_{3}\right) ; 19.0\left(\mathrm{CH}_{2} \mathrm{CH}_{2} \mathrm{CH}_{2} \mathrm{CH}_{3}\right) ; 20.0$ $\left(\mathrm{CH}_{2} \mathrm{C}_{6} \mathrm{H}_{4}\left(\mathrm{CH}_{3}\right)-3\right) ; 32.3\left(\mathrm{CH}_{2} \mathrm{CH}_{2} \mathrm{CH}_{2} \mathrm{CH}_{3}\right) ; 47.8\left(\mathrm{CH}_{2} \mathrm{CH}_{2} \mathrm{CH}_{2} \mathrm{CH}_{3}\right) ; 50.8\left(\mathrm{CH}_{2} \mathrm{C}_{6} \mathrm{H}_{4}\left(\mathrm{CH}_{3}\right)-3\right) ; 87.4$, 99.8, 100.6, 109.7, 111.9, 114.4, 123.4, 124.0, 132.8, 134.7 (arom. $C, \mathrm{NC}_{6} \mathrm{H}_{4} \mathrm{~N}$ and $\mathrm{CH}_{2} \mathrm{C}_{6} \mathrm{H}_{4}\left(\mathrm{CH}_{3}\right)-3$ ); 
181.3 (Ru- $C_{\text {carbene }}$ ) ppm (Figure S5). Elemental analysis calcd (\%) for $\mathrm{C}_{19} \mathrm{H}_{22} \mathrm{Cl}_{2} \mathrm{~N}_{2} \mathrm{Ru}(\mathrm{Mr}=450.40)$ : C 50.67, H 4.92, N 6.22; found (\%): C 50.74, H 4.95, N 6.26.

Dichloro-[1-(2,3,5,6-tetramethylbenzyl)-3-(n-butyl)benzimidazol-2-ylidene]ruthenium(II), 2b: (0.393 g, yield $80 \%){ }^{1} \mathrm{H}$ NMR $\left(300 \mathrm{MHz}, \mathrm{CDCl}_{3}, 25^{\circ} \mathrm{C}\right): \delta=0.94\left(\mathrm{t},{ }^{3} \mathrm{~J}=7.4 \mathrm{~Hz}, 3 \mathrm{H}, \mathrm{CH}_{2} \mathrm{CH}_{2} \mathrm{CH}_{2} \mathrm{CH}_{3}\right) ; 1.44$ (hext, $\left.{ }^{3} J=7.5 \mathrm{~Hz}, 2 \mathrm{H}, \mathrm{CH}_{2} \mathrm{CH}_{2} \mathrm{CH}_{2} \mathrm{CH}_{3}\right) ; 1.85$ (pent, $\left.{ }^{3} \mathrm{~J}=7.5 \mathrm{~Hz}, 2 \mathrm{H}, \mathrm{CH}_{2} \mathrm{CH}_{2} \mathrm{CH}_{2} \mathrm{CH}_{3}\right) ; 1.99$ and $2.13(\mathrm{~s}, 12 \mathrm{H}$, $\left.\mathrm{CH}_{2} \mathrm{C}_{6} \mathrm{H}\left(\mathrm{CH}_{3}\right)_{4}-2,3,5,6\right) ; 4.42-4.48\left(\mathrm{~m}, 2 \mathrm{H}, \mathrm{CH}_{2} \mathrm{CH}_{2} \mathrm{CH}_{2} \mathrm{CH}_{3}\right) ; 5.06\left(\mathrm{~s}, 2 \mathrm{H}, \mathrm{CH}_{2} \mathrm{C}_{6} \mathrm{H}\left(\mathrm{CH}_{3}\right)_{4}-2,3,5,6\right) ; 5.54$ (s, $1 \mathrm{H}$, arom. $\left.\mathrm{CH}, \mathrm{CH}_{2} \mathrm{C}_{6} \mathrm{H}\left(\mathrm{CH}_{3}\right)_{4}-2,3,5,6\right) ; 7.32-7.38\left(\mathrm{~m}, 2 \mathrm{H}\right.$, arom. $\mathrm{CH}$ of benzimidazole, $\left.\mathrm{NC}_{6} \mathrm{H}_{4} \mathrm{~N}\right)$; 7.41-7.44 (m, 2H, arom. $\mathrm{CH}$ of benzimidazole, $\left.\mathrm{NC}_{6} \mathrm{H}_{4} \mathrm{~N}\right)$ ppm. ${ }^{13} \mathrm{C} \mathrm{NMR}\left(75 \mathrm{MHz}, \mathrm{CDCl}_{3}, 25^{\circ} \mathrm{C}\right)$ : $\delta=13.8\left(\mathrm{CH}_{2} \mathrm{CH}_{2} \mathrm{CH}_{2} \mathrm{CH}_{3}\right) ; 13.9$ and $18.3\left(\mathrm{CH}_{2} \mathrm{C}_{6} \mathrm{H}\left(\mathrm{CH}_{3}\right)_{4}-2,3,5,6\right) ; 20.0\left(\mathrm{CH}_{2} \mathrm{CH}_{2} \mathrm{CH}_{2} \mathrm{CH}_{3}\right) ; 32.3$ $\left(\mathrm{CH}_{2} \mathrm{CH}_{2} \mathrm{CH}_{2} \mathrm{CH}_{3}\right) ; 45.9\left(\mathrm{CH}_{2} \mathrm{C}_{6} \mathrm{H}\left(\mathrm{CH}_{3}\right)_{4}-2,3,5,6\right) ; 47.7\left(\mathrm{CH}_{2} \mathrm{CH}_{2} \mathrm{CH}_{2} \mathrm{CH}_{3}\right) ; 84.5,90.7,97.5,109.6,110.2$, 111.7, 123.1, 123.5, 133.0, 135.0 (arom. $C, \mathrm{NC}_{6} \mathrm{H}_{4} \mathrm{~N}$ and $\left.\mathrm{CH}_{2} \mathrm{C}_{6} \mathrm{H}\left(\mathrm{CH}_{3}\right)_{4}-2,3,5,6\right) ; 184.9$ (Ru- $C_{\text {carbene }}$ ) ppm (Figure S6). Elemental analysis calcd (\%) for $\mathrm{C}_{22} \mathrm{H}_{28} \mathrm{Cl}_{2} \mathrm{~N}_{2} \mathrm{Ru}(\mathrm{Mr}=492.40)$ : C 53.66, H 5.73, N 5.69; found (\%): C 53.64, H 5.72, N 5.68.

Dichloro-[1-(2,3,4,5,6-Pentamethylbenzyl)-3-(n-Butyl)Benzimidazol-2-Ylidene]Ruthenium(II), 2c: (0.415 g, yield $82 \%){ }^{1} \mathrm{H}$ NMR $\left(300 \mathrm{MHz}, \mathrm{CDCl}_{3}, 25{ }^{\circ} \mathrm{C}\right): \delta=0.94\left(\mathrm{t},{ }^{3} \mathrm{~J}=7.4 \mathrm{~Hz}, 3 \mathrm{H}, \mathrm{CH}_{2} \mathrm{CH}_{2} \mathrm{CH}_{2} \mathrm{CH}_{3}\right)$; 1.44 (hext, ${ }^{3} \mathrm{~J}=7.5 \mathrm{~Hz}, 2 \mathrm{H}, \mathrm{CH}_{2} \mathrm{CH}_{2} \mathrm{CH}_{2} \mathrm{CH}_{3}$ ); 1.84 (pent, ${ }^{3} \mathrm{~J}=7.5 \mathrm{~Hz}, 2 \mathrm{H}, \mathrm{CH}_{2} \mathrm{CH}_{2} \mathrm{CH}_{2} \mathrm{CH}_{3}$ ); 2.03, 2.09 and $2.21\left(\mathrm{~s}, 15 \mathrm{H}, \mathrm{CH}_{2} \mathrm{C}_{6}\left(\mathrm{CH}_{3}\right)_{5}-2,3,4,5,6\right) ; 4.42-4.47\left(\mathrm{~m}, 2 \mathrm{H}, \mathrm{CH}_{2} \mathrm{CH}_{2} \mathrm{CH}_{2} \mathrm{CH}_{3}\right) ; 5.05$ (s, $\left.2 \mathrm{H}, \mathrm{CH}_{2} \mathrm{C}_{6}\left(\mathrm{CH}_{3}\right)_{5}-2,3,4,5,6\right) ; 7.29-7.38\left(\mathrm{~m}, 2 \mathrm{H}\right.$, arom. $\mathrm{CH}$ of benzimidazole, $\left.\mathrm{NC}_{6} \mathrm{H}_{4} \mathrm{~N}\right) ; 7.39-7.42$ $\left(\mathrm{m}, 2 \mathrm{H}\right.$, arom. $\mathrm{CH}$ of benzimidazole, $\left.\mathrm{NC}_{6} \mathrm{H}_{4} \mathrm{~N}\right) \mathrm{ppm} .{ }^{13} \mathrm{C} \mathrm{NMR}\left(75 \mathrm{MHz}, \mathrm{CDCl}_{3}, 25{ }^{\circ} \mathrm{C}\right)$ : $\delta=13.9\left(\mathrm{CH}_{2} \mathrm{CH}_{2} \mathrm{CH}_{2} \mathrm{CH}_{3}\right) ; 14.9,15.0$ and $15.7\left(\mathrm{CH}_{2} \mathrm{C}_{6}\left(\mathrm{CH}_{3}\right)_{5}-2,3,4,5,6\right) ; 20.0\left(\mathrm{CH}_{2} \mathrm{CH}_{2} \mathrm{CH}_{2} \mathrm{CH}_{3}\right)$; $32.3\left(\mathrm{CH}_{2} \mathrm{CH}_{2} \mathrm{CH}_{2} \mathrm{CH}_{3}\right) ; 46.4\left(\mathrm{CH}_{2} \mathrm{C}_{6}\left(\mathrm{CH}_{3}\right)_{5}-2,3,4,5,6\right) ; 47.6\left(\mathrm{CH}_{2} \mathrm{CH}_{2} \mathrm{CH}_{2} \mathrm{CH}_{3}\right) ; 86.0,94.5,97.9,107.9$, 109.5, 111.5, 123.0, 123.4, 133.2, 135.0 (arom. $C, \mathrm{NC}_{6} \mathrm{H}_{4} \mathrm{~N}$ and $\left.\mathrm{CH}_{2} \mathrm{C}_{6}\left(\mathrm{CH}_{3}\right)_{5}-2,3,4,5,6\right) ; 186.0\left(\mathrm{Ru}-\mathrm{C}_{\text {carbene }}\right.$ ) ppm (Figure S7). Elemental analysis calcd (\%) for $\mathrm{C}_{23} \mathrm{H}_{30} \mathrm{Cl}_{2} \mathrm{~N}_{2} \mathrm{Ru}(\mathrm{Mr}=506.50)$ : C 54.54, H 5.97, N 5.53; found (\%): C 54.57, H 5.98, N 5.54.

Dichloro-[1-(4-tert-butylbenzyl)-3-(n-butyl)benzimidazol-2-ylidene]ruthenium(II), 2d: (0.349 g, yield 71\%) ${ }^{1} \mathrm{H}$ NMR $\left(300 \mathrm{MHz}, \mathrm{CDCl}_{3}, 25{ }^{\circ} \mathrm{C}\right): \delta=0.97\left(\mathrm{t},{ }^{3} \mathrm{~J}=7.1 \mathrm{~Hz}, 3 \mathrm{H}, \mathrm{CH}_{2} \mathrm{CH}_{2} \mathrm{CH}_{2} \mathrm{CH}_{3}\right) ; 1.26$ (s, 9H, $\left.\mathrm{CH}_{2} \mathrm{C}_{6} \mathrm{H}_{4}\left(\mathrm{C}\left(\mathrm{CH}_{3}\right)_{3}\right)-4\right) ; 1.46$ (hext, $\left.{ }^{3} \mathrm{~J}=6.4 \mathrm{~Hz}, 2 \mathrm{H}, \mathrm{CH}_{2} \mathrm{CH}_{2} \mathrm{CH}_{2} \mathrm{CH}_{3}\right) ; 1.93-1.95$ (m, $\left.2 \mathrm{H}, \mathrm{CH}_{2} \mathrm{CH}_{2} \mathrm{CH}_{2} \mathrm{CH}_{3}\right) ; 4.65\left(\mathrm{~m}, 2 \mathrm{H}, \mathrm{CH}_{2} \mathrm{CH}_{2} \mathrm{CH}_{2} \mathrm{CH}_{3}\right) ; 5.40(\mathrm{dd}, \mathrm{J}=52.0,14.7 \mathrm{~Hz}, 2 \mathrm{H}$,

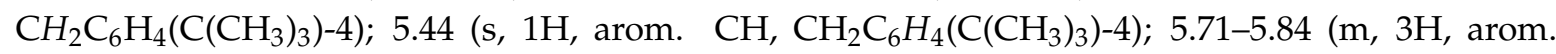

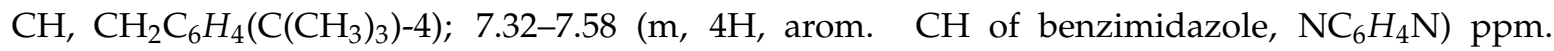
${ }^{13} \mathrm{C}$ NMR $\left(75 \mathrm{MHz}, \mathrm{CDCl}_{3}, 25{ }^{\circ} \mathrm{C}\right): \delta=13.7\left(\mathrm{CH}_{2} \mathrm{CH}_{2} \mathrm{CH}_{2} \mathrm{CH}_{3}\right) ; 19.9\left(\mathrm{CH}_{2} \mathrm{CH}_{2} \mathrm{CH}_{2} \mathrm{CH}_{3}\right) ; 31.2$ $\left(\mathrm{CH}_{2} \mathrm{C}_{6} \mathrm{H}_{4}\left(\mathrm{C}\left(\mathrm{CH}_{3}\right)_{3}\right)-4\right) ; 31.7\left(\mathrm{CH}_{2} \mathrm{CH}_{2} \mathrm{CH}_{2} \mathrm{CH}_{3}\right) ; 34.6\left(\mathrm{CH}_{2} \mathrm{C}_{6} \mathrm{H}_{4}\left(\mathrm{C}\left(\mathrm{CH}_{3}\right)_{3}\right)-4\right) ; 48.0\left(\mathrm{CH}_{2} \mathrm{CH}_{2} \mathrm{CH}_{2} \mathrm{CH}_{3}\right)$; $52.0\left(\mathrm{CH}_{2} \mathrm{C}_{6} \mathrm{H}_{4}\left(\mathrm{C}\left(\mathrm{CH}_{3}\right)_{3}\right)-4\right) ; 81.6,96.5,112.8,113.9,126.0,126.3,126.4,128.3,130.5,131.4,131.5,151.7$ (arom. C, $\mathrm{NC}_{6} \mathrm{H}_{4} \mathrm{~N}$ and $\left.\mathrm{CH}_{2} \mathrm{C}_{6} \mathrm{H}_{4}\left(\mathrm{C}\left(\mathrm{CH}_{3}\right)_{3}\right)-4\right) ; 186.1$ (Ru- $\mathrm{C}_{\text {carbene }}$ ) ppm (Figure S8). Elemental analysis calcd (\%) for $\mathrm{C}_{22} \mathrm{H}_{28} \mathrm{Cl}_{2} \mathrm{~N}_{2} \mathrm{Ru}(\mathrm{Mr}=492.40)$ : C 53.66, $\mathrm{H}$ 5.73, N 5.69; found (\%): C 53.74, H 5.78, N 5.76.

Dichloro-[1-(2,3,5,6-tetramethylbenzyl)-3-(4-methoxybenzyl)benzimidazol-2-ylidene]ruthenium(II), 2e: $(0.422$ $\mathrm{g}$, yield 76\%) ${ }^{1} \mathrm{H}$ NMR $\left(300 \mathrm{MHz}, \mathrm{CDCl}_{3}, 25^{\circ} \mathrm{C}\right): \delta=2.04$ and $2.16\left(\mathrm{~s}, 12 \mathrm{H}, \mathrm{CH}_{2} \mathrm{C}_{6} \mathrm{H}\left(\mathrm{CH}_{3}\right){ }_{4}-2,3,5,6\right)$; $3.74\left(\mathrm{~s}, 3 \mathrm{H}, \mathrm{CH}_{2} \mathrm{C}_{6} \mathrm{H}_{4}\left(\mathrm{OCH}_{3}\right)-4\right)$; 5.12 (s, 2H, $\left.\mathrm{CH}_{2} \mathrm{C}_{6} \mathrm{H}\left(\mathrm{CH}_{3}\right)_{4}-2,3,5,6\right) ; 5.59$ (s, $1 \mathrm{H}$, arom. $\mathrm{CH}$ $\left.\mathrm{CH}_{2} \mathrm{C}_{6} \mathrm{H}\left(\mathrm{CH}_{3}\right)_{4}-2,3,5,6\right) ; 5.68\left(\mathrm{~s}, 2 \mathrm{H}, \mathrm{CH}_{2} \mathrm{C}_{6} \mathrm{H}_{4}\left(\mathrm{OCH}_{3}\right)-4\right) ; 6.77\left(\mathrm{~d},{ }^{3} \mathrm{~J}=8.7 \mathrm{~Hz}, 2 \mathrm{H}\right.$, arom. $\mathrm{CH}, \mathrm{NC}_{6} \mathrm{H}_{4} \mathrm{~N}$ and $\left.\mathrm{CH}_{2} \mathrm{C}_{6} \mathrm{H}_{4}\left(\mathrm{OCH}_{3}\right)-4\right) ; 6.99\left(\mathrm{~d}, J=8.1 \mathrm{~Hz}, 1 \mathrm{H}\right.$, arom. $\mathrm{CH}, \mathrm{NC}_{6} \mathrm{H}_{4} \mathrm{~N}$ and $\left.\mathrm{CH}_{2} \mathrm{C}_{6} \mathrm{H}_{4}\left(\mathrm{OCH}_{3}\right)-4\right)$; 7.06-7.12 (m, $1 \mathrm{H}$, arom. $\mathrm{CH}, \mathrm{NC}_{6} \mathrm{H}_{4} \mathrm{~N}$ and $\left.\mathrm{CH}_{2} \mathrm{C}_{6} \mathrm{H}_{4}\left(\mathrm{OCH}_{3}\right)-4\right) ; 7.20-7.28\left(\mathrm{~m}, 3 \mathrm{H}\right.$, arom. $\mathrm{CH}, \mathrm{NC}_{6} \mathrm{H}_{4} \mathrm{~N}$ and $\left.\mathrm{CH}_{2} \mathrm{C}_{6} \mathrm{H}_{4}\left(\mathrm{OCH}_{3}\right)-4\right) ; 7.42\left(\mathrm{~d},{ }^{3} \mathrm{~J}=8.0 \mathrm{~Hz}, 1 \mathrm{H}\right.$, arom. $\mathrm{CH}, \mathrm{NC}_{6} \mathrm{H}_{4} \mathrm{~N}$ and $\left.\mathrm{CH}_{2} \mathrm{C}_{6} \mathrm{H}_{4}\left(\mathrm{OCH}_{3}\right)-4\right)$ ppm. ${ }^{13} \mathrm{C}$ NMR $\left(75 \mathrm{MHz}, \mathrm{CDCl}_{3}, 25{ }^{\circ} \mathrm{C}\right): \delta=13.9$ and $18.3\left(\mathrm{CH}_{2} \mathrm{C}_{6} \mathrm{H}\left(\mathrm{CH}_{3}\right)_{4}-2,3,5,6\right) ; 46.0$ $\left(\mathrm{CH}_{2} \mathrm{C}_{6} \mathrm{H}\left(\mathrm{CH}_{3}\right)_{4}-2,3,5,6\right) ; 52.3\left(\mathrm{CH}_{2} \mathrm{C}_{6} \mathrm{H}_{4}\left(\mathrm{OCH}_{3}\right)-4\right) ; 55.2\left(\mathrm{CH}_{2} \mathrm{C}_{6} \mathrm{H}_{4}\left(\mathrm{OCH}_{3}\right)-4\right) ;$ 84.4, 90.6, 98.0, 109.5, 110.6, 113.0, 113.6, 123.1, 123.5, 129.0, 129.3, 133.2, 135.0, 158.8 (arom. C, $\mathrm{NC}_{6} \mathrm{H}_{4} \mathrm{~N}$, $\mathrm{CH}_{2} \mathrm{C}_{6} \mathrm{H}\left(\mathrm{CH}_{3}\right)_{4}-2,3,5,6$ and $\left.\mathrm{CH}_{2} \mathrm{C}_{6} \mathrm{H}_{4}\left(\mathrm{OCH}_{3}\right)-4\right) ; 185.2$ (Ru- $\mathrm{C}_{\text {carbene }}$ ) ppm (Figure S9). Elemental analysis calcd (\%) for $\mathrm{C}_{26} \mathrm{H}_{28} \mathrm{Cl}_{2} \mathrm{~N}_{2} \mathrm{ORu}(\mathrm{Mr}=556.50)$ : $\mathrm{C} 56.12, \mathrm{H} 5.07, \mathrm{~N} 5.03$; found (\%): $\mathrm{C} 56.16, \mathrm{H}$ $5.06, \mathrm{~N} 5.03$. 


\subsection{General Procedure for the Direct Catalytic Arylation of 2-Phenylpyridine with (Hetero)Aryl Chlorides}

Each $\left[\mathrm{RuCl}_{2}\left(\eta^{6}, \eta^{1}\right.\right.$-arene- $\left.\left.\mathrm{CH}_{2}-\mathrm{NHC}\right)\right]$ complex $(2 \mathbf{a}-\mathbf{e})(0.025 \mathrm{mmol})$ and KOAc $(0.05 \mathrm{mmol})$ was stirred in water $(2 \mathrm{~mL})$ at room temperature for $1 \mathrm{~h}$, and then 2-phenylpyridine ( $0.5 \mathrm{mmol})$, (hetero)aryl chloride $(1.25 \mathrm{mmol})$ and $\mathrm{Cs}_{2} \mathrm{CO}_{3}(1.50 \mathrm{mmol})$ were added. The resulting mixture was stirred at $100{ }^{\circ} \mathrm{C}$ for different durations. After completion of the reaction, the reaction mixture was cooled to room temperature. Dichloromethane was added to this mixture and organic phase was extracted. The extracted organic phase was dried over $\mathrm{MgSO}_{4}$ and concentrated under vacuum. The remaining residue was purified by column chromatography on silica gel (pentane/diethylether mixture, 1:5 v/v). The ortho-arylated products A and B conversion and ratio were determined by GC and GC-MS analyses.

\subsection{Single Crystal X-ray Diffraction and Structure Analysis}

A crystal of compound $\mathbf{2 b}$ with dimensions of $0.31 \times 0.13 \times 0.07 \mathrm{~mm}^{3}$ was mounted on the tip of a glass fiber using epoxy and placed on a Bruker SMART 1000 CCD (Atlanta, GA, USA) sealed tube diffractometer with graphite monochromated $\operatorname{MoK} \alpha(0.71073 \AA)$ radiation. Data were measured at 373(2) K using a series of combinations of phi and omega scans. Data collection, indexing and initial cell refinements were all carried out using SMART software [55]. Frame integration and final cell refinements were done using SAINT software [56]. The structure was solved using Direct methods and difference Fourier techniques (SHELXTL, V6.12) [57]. Hydrogen atoms were placed in their expected chemical positions using the HFIX command and were included in the final cycles of least squares with isotropic Uijs related to the atoms ridden upon. All non-hydrogen atoms were refined anisotropically. Structure solution, refinement, graphics and generation of publication materials were performed using the software SHELXTL, Version 6.12 [57].

\section{Conclusions}

The above described reactions demonstrate that water can be used as solvent for direct $\mathrm{C}-\mathrm{H}$ bond functionalization. It is noteworthy that, in addition to its role as safe, clean, and recoverable solvent, water also plays the role of a positive catalyst partner, as in the direct selective mono(hetero)arylation of 2-phenylpyridine. We have synthesized and characterized new benzimidazolium halides (1a-e) and five new $\left[\mathrm{RuCl}_{2}\left(\eta^{6}, \eta^{1}\right.\right.$-arene-CH$\left.\left.{ }_{2}-\mathrm{NHC}\right)\right]$ complexes (2a-e). Complexes $\mathbf{2 a}-\mathbf{e}$ with $\mathrm{KOAc}$ partner showed good catalytic activity for the direct arylation of 2-phenylpyridine with (hetero)aryl chlorides in water. The catalytic activity of $\left[\mathrm{RuCl}_{2}\left(\eta^{6}, \eta^{1}\right.\right.$-arene- $\left.\left.\mathrm{CH}_{2}-\mathrm{NHC}\right)\right]$ for mono heteroarylation of heterocyclic arene (pyridine arene) has the potential to reach bidentate new ligands in the future. There is no serious doubt that this field of research will increase significantly in the future, hopefully making another step towards more environmentally friendly and energy/resources saving processes.

Supplementary Materials: Supplementary materials are available online. CCDC-1823696 contains the supplementary crystallographic data for this paper. These data can be obtained free of charge via www.ccdc. cam.ac.uk/data_request/cif, or by e-mailing data_request@ccdc.cam.ac.uk, or by contacting The Cambridge Crystallographic Data Centre, 12 Union Road, Cambridge CB2 1EZ, UK; Fax: +44(0)1223-336033.

Acknowledgments: This work was financially supported by the Technological and Scientific Research Council of Turkey TÜBITAK-BOSPHORUS (109T605).

Author Contributions: All authors contributed equally to this work.

Conflicts of Interest: The authors declare that they have no conflict of interest.

\section{References}

1. Hassan, J.; Sévignon, M.; Gozzi, C.; Schulz, E.; Lemaire, M. Aryl-aryl bond formation one century after the discovery of the Ullmann reaction. Chem. Rev. 2002, 102, 1359-1470. [CrossRef] [PubMed]

2. Knight, D.W. Comprehensive Organic Synthesis, 1st ed.; Trost, B.M., Fleming, I., Eds.; Pergamon: London, UK, 1991; Volume 3, pp. 481-520, ISBN 0080359299. 
3. Kumada, M. Nickel and palladium complex catalyzed cross-coupling reactions of organometallic reagents with organic halides. Pure Appl. Chem. 1980, 52, 669-679. [CrossRef]

4. Negishi, E. Palladium- or Nickel-catalyzed cross coupling. A new selective method for carbon-carbon bond formation. Acc. Chem. Res. 1982, 15, 340-348. [CrossRef]

5. Miyaura, N.; Suzuki, A. Palladium-catalyzed cross-coupling reactions of organoboron compounds. Chem. Rev. 1995, 95, 2457-2483. [CrossRef]

6. Hiyama, T.; Hatanaka, Y. Palladium-catalyzed cross-coupling reaction of organometalloids through activation with fluoride ion. Pure Appl. Chem. 1994, 66, 1471-1478. [CrossRef]

7. Stille, J.K. The palladium-catalyzed cross-coupling reactions of organotin reagents with organic electrophiles [new synthetic methods (58)]. Angew. Chem. Int. Ed. Engl. 1986, 25, 508-524. [CrossRef]

8. De Meijere, A.; Diederich, F. (Eds.) Metal-Catalyzed Cross-Coupling Reactions, 2nd ed.; Wiley-VCH: Weinheim, Germany, 2004; Volume 1, ISBN 978-3-527-30518-6.

9. Nicolaou, K.C.; Bulger, P.G.; Sarlah, D. Palladium-catalyzed cross-coupling reactions in total synthesis. Angew. Chem. Int. Ed. 2005, 44, 4442-4489. [CrossRef] [PubMed]

10. Shilov, A.E.; Shul'pin, G.B. Activation of C-H bonds by metal complexes. Chem. Rev. 1997, 97, $2879-2932$. [CrossRef] [PubMed]

11. Kakiuchi, F.; Murai, S. Activation of Unreactive Bonds and Organic Synthesis; Murai, S., Ed.; Springer: Berlin, Germany, 1999; pp. 47-79, ISBN 978-3-540-68525-8.

12. Dyker, G. Transition metal catalyzed coupling reactions under C-H activation. Angew. Chem. Int. Ed. 1999, 38, 1698-1712. [CrossRef]

13. Robin, B.; Bedford, R.B.; Limmert, M.E. Catalytic intermolecular ortho-arylation of phenols. J. Org. Chem. 2003, 68, 8669-8682. [CrossRef]

14. Goj, L.A.; Gunnoe, T.B. Developments in catalytic aromatic C-H transformations: Promising tools for organic synthesis. Curr. Org. Chem. 2005, 9, 671-685. [CrossRef]

15. Campeau, L.-C.; Fagnou, K. Palladium-catalyzed direct arylation of simple arenes in synthesis of biaryl molecules. Chem. Commun. 2006, 12, 1253-1264. [CrossRef] [PubMed]

16. Stuart, D.R.; Fagnou, K. The catalytic cross-coupling of unactivated arenes. Science 2007, 316, 1172-1175. [CrossRef] [PubMed]

17. Thirunavukkarasu, V.S.; Parthasarathy, K.; Cheng, C.H. Synthesis of fluorenones from aromatic aldoxime ethers and aryl halides by palladium-catalyzed dual C-H activation and Heck cyclization. Angew. Chem. Int. Ed. 2008, 47, 9462-9465. [CrossRef] [PubMed]

18. Chen, X.; Engle, K.M.; Wang, D.H.; Yu, J.Q. Palladium(II)-catalyzed C-H activation/C-C cross-coupling reactions: Versatility and practicality. Angew. Chem. Int. Ed. 2009, 48, 5094-5115. [CrossRef] [PubMed]

19. Bellina, F.; Rossi, R. Recent advances in the synthesis of (hetero)aryl-substituted heteroarenes via transition metal-catalysed direct (hetero)arylation of heteroarene $\mathrm{C}-\mathrm{H}$ bonds with aryl halides or pseudohalides, diaryliodonium salts, and potassium aryltrifluoroborates. Tetrahedron 2009, 65, 10269-10310. [CrossRef]

20. Ackermann, L.; Vicente, R.; Kapdi, A.R. Transition-metal-catalyzed direct arylation of (hetero)arenes by C-H bond cleavage. Angew. Chem. Int. Ed. 2009, 48, 9792-9826. [CrossRef] [PubMed]

21. Thirunavukkarasu, V.S.; Parthasarathy, K.; Cheng, C.H. One-pot synthesis of diarylmethylidenefluorenes and phenanthrenes by palladium-catalyzed multiple C-H bond functionalization. Chem. Eur. J. 2010, 16, 1436-1440. [CrossRef] [PubMed]

22. Gandeepan, P.; Parthasarathy, K.; Cheng, C.H. Synthesis of phenanthrone derivatives from sec-alkyl aryl ketones and aryl Halides via a palladium-catalyzed dual C-H bond activation and enolate cyclization. J. Am. Chem. Soc. 2010, 132, 8569-8571. [CrossRef] [PubMed]

23. Rousseaux, S.; Davi, M.; Sofack-Kreutzer, J.; Pierre, C.; Kefalidis, C.E.; Clot, E.; Fagnou, K.; Baudoin, O. Intramolecular palladium-catalyzed alkane $\mathrm{C}-\mathrm{H}$ arylation from aryl chlorides. J. Am. Chem. Soc. 2010, 132, 10706-10716. [CrossRef] [PubMed]

24. Li, W.; Xu, Z.P.; Sun, P.P.; Jiang, X.Q.; Fang, M. Synthesis of biphenyl-2-carbonitrile derivatives via a palladium-catalyzed $\mathrm{sp}^{2} \mathrm{C}-\mathrm{H}$ bond activation using cyano as a directing group. Org. Lett. 2011, 13, 1286-1289. [CrossRef] [PubMed]

25. Lewis, L.N.; Smith, J.F. Catalytic C-C bond formation via ortho-metalated complexes. J. Am. Chem. Soc. 1986, 108, 2728-2735. [CrossRef] 
26. Murai, S.; Kakiuchi, F.; Sekine, S.; Tanaka, Y.; Kamatani, A.; Sonoda, M.; Chatani, N. Efficient catalytic addition of aromatic carbon-hydrogen bonds to olefins. Nature 1993, 366, 529-531. [CrossRef]

27. Oi, S.; Fukita, S.; Hirata, N.; Watanuki, N.; Miyano, S.; Inoue, Y. Ruthenium complex-catalyzed direct ortho arylation and alkenylation of 2-arylpyridines with organic halides. Org. Lett. 2001, 3, 2579-2581. [CrossRef] [PubMed]

28. Prades, A.; Poyatos, M.; Peris, E. $\left(\eta^{6}\right.$-Arene)ruthenium( $N$-heterocyclic carbene) complexes for the chelation-assisted arylation and deuteration of arylpyridines: Catalytic studies and mechanistic insights. Adv. Synth. Catal. 2010, 352, 1155-1162. [CrossRef]

29. Ackermann, L. Phosphine oxides as preligands in ruthenium-catalyzed arylations via C-H bond functionalization using aryl chlorides. Org. Lett. 2005, 7, 3123-3125. [CrossRef] [PubMed]

30. Ackermann, L. Carboxylate-assisted transition-metal-catalyzed C-H bond functionalizations: Mechanism and scope. Chem. Rev. 2011, 111, 1315-1345. [CrossRef] [PubMed]

31. Ackermann, L.; Vicente, R.; Althammer, A. Assisted ruthenium-catalyzed C-H bond activation: Carboxylic acids as cocatalysts for generally applicable direct arylations in apolar solvents. Org. Lett. 2008, 10, 2299-2302. [CrossRef] [PubMed]

32. Li, W.; Arockiam, P.B.; Fischmeister, C.; Bruneau, C.; Dixneuf, P.H. C-H bond functionalisation with $\left[\mathrm{RuH}(\mathrm{codyl})_{2}\right]_{\mathrm{BF}}$ catalyst precursor. Green Chem. 2011, 13, 2315-2319. [CrossRef]

33. Davies, D.L.; Al-Duaij, O.; Fawcett, J.; Giardiello, M.; Hilton, S.T.; Russell, D.R. Room-temperature cyclometallation of amines, imines and oxazolines with $\left[\mathrm{MCl}_{2} \mathrm{Cp}^{*}\right]_{2}(\mathrm{M}=\mathrm{Rh}$, Ir $)$ and $\left[\mathrm{RuCl}_{2}(p \text {-cymene })\right]_{2}$. Dalton Trans. 2003, 21, 4132-4138. [CrossRef]

34. Stefane, B.; Fabris, J.; Pozgan, F. C-H bond functionalization of arylpyrimidines catalyzed by an in situ generated ruthenium(II) carboxylate system and the construction of tris(heteroaryl)-substituted benzenes. Eur. J. Org. Chem. 2011, 19, 3474-3481. [CrossRef]

35. Aihara, Y.; Chatani, N. Ruthenium-catalyzed direct arylation of $\mathrm{C}-\mathrm{H}$ bonds in aromatic amides containing a bidentate directing group: Significant electronic effects on arylation. Chem. Sci. 2013, 4, 664-670. [CrossRef]

36. Shan, C.; Luo, X.; Qi, X.; Liu, S.; Li, Y.; Lan, Y. Mechanism of ruthenium-catalyzed direct arylation of C-H bonds in aromatic amides: A computational study. Organometallics 2016, 35, 1440-1445. [CrossRef]

37. Zha, G.F.; Qin, H.L.; Kantchev, E.A.B. Ruthenium-catalyzed direct arylations with aryl chlorides. RSC Adv. 2016, 6, 30875-30885. [CrossRef]

38. Nareddy, P.; Jordan, F.; Szostak, M. Ruthenium(II)-catalyzed ortho-C-H arylation of diverse N-heterocycles with aryl silanes by exploiting solvent-controlled $N$-coordination. Org. Biomol. Chem. 2017, 15, 4783-4788. [CrossRef] [PubMed]

39. Özdemir, I.; Demir, S.; Cetinkaya, B.; Gourlaouen, C.; Maseras, F.; Bruneau, C.; Dixneuf, P.H. Direct arylation of arene $\mathrm{C}-\mathrm{H}$ bonds by cooperative action of NHCarbene-ruthenium(II) catalyst and carbonate via proton abstraction mechanism. J. Am. Chem. Soc. 2008, 130, 1156-1157. [CrossRef] [PubMed]

40. Demir, S.; Özdemir, İ.; Çetinkaya, B. Synthesis and catalytic properties of novel ruthenium $N$-heterocyclic-carbene complexes. J. Organomet. Chem. 2009, 694, 4025-4031. [CrossRef]

41. Özdemir, I.; Demir, S.; Gürbüz, N.; Çetinkaya, B.; Toupet, L.; Bruneau, C.; Dixneuf, P.H. Synthesis, characterization and catalytic activity of new $\mathrm{N}$-heterocyclic bis(carbene)ruthenium complexes. Eur. J. Inorg. Chem. 2009, 13, 1942-1949. [CrossRef]

42. Ackermann, L.; Kapdi, A.R.; Potukuchi, H.K.; Kozhushkov, S.I. Syntheses via C-H Bond Functionalizations. In Handbook of Green Chemistry—Green Processes; Li, C.-J., Ed.; Wiley-VCH: Weinheim, Germany, 2012; pp. 259-305.

43. Arockiam, P.; Poirier, V.; Fischmeister, C.; Bruneau, C.; Dixneuf, P.H. Diethyl carbonate as a solvent for ruthenium catalysed C-H bond functionalization. Green Chem. 2009, 11, 1871-1875. [CrossRef]

44. Arockiam, P.B.; Fischmeister, C.; Bruneau, C.; Dixneuf, P.H. C-H bond functionalization in water catalyzed by carboxylato ruthenium(II) systems. Angew. Chem. Int. Ed. 2010, 49, 6629-6632. [CrossRef] [PubMed]

45. Arockiam, P.B.; Fischmeister, C.; Bruneau, C.; Dixneuf, P.H. Ruthenium(II)-catalyzed selective monoarylation in water and sequential functionalisations of C-H bonds. Green. Chem. 2013, 15, 67-71. [CrossRef]

46. Li, B.; Devaraj, K.; Darcel, C.; Dixneuf, P.H. Catalytic C-H bond arylation of aryl imines and oxazolines in water with ruthenium(II)-acetate catalyst. Tetrahedron 2012, 68, 5179-5184. [CrossRef]

47. Singh, K.S.; Dixneuf, P.H. Direct C-H bond arylation in water promoted by $(\mathrm{O}, \mathrm{O})$ - and $(\mathrm{O}, \mathrm{N})$-chelate ruthenium(II) catalysts. ChemCatChem. 2013, 5, 1313-1316. [CrossRef] 
48. Emmanuel, F.F.; Bruneau, B.; Dixneuf, P.H.; Jutand, A. Autocatalysis for C-H bond activation by ruthenium(II) complexes in catalytic arylation of functional arenes. J. Am. Chem. Soc. 2011, 133, 10161-10170. [CrossRef]

49. Fabre, I.; von Wolff, N.; Le Duc, G.; Flegeau, E.F.; Bruneau, B.; Dixneuf, P.H.; Jutand, A. Autocatalytic intermolecular versus intramolecular deprotonation in $\mathrm{C}-\mathrm{H}$ bond activation of functional arenes by ruthenium(II) or palladium(II) complexes. Chem. Eur. J. 2013, 19, 7595-7604. [CrossRef] [PubMed]

50. Günal, S.; Kaloğlu, N.; Özdemir, İ.; Demir, S.; Özdemir, İ. Novel benzimidazolium salts and their silver complexes: Synthesis and antibacterial properties. Inorg. Chem. Commun. 2012, 21, 142-146. [CrossRef]

51. Demir, S.; Özdemir, İ.; Şahin, O.; Çetinkaya, B.; Büyükgüngör, O. Synthesis and catalytic activity of novel benizimidazlolinylidene-ruthenium(II) complexes. Synlett 2010, 3, 496-500. [CrossRef]

52. Çetinkaya, B.; Demir, S.; Özdemir, I.; Toupet, L.; Semeril, D.; Bruneau, C.; Dixneuf, H.P. $\eta^{6}$-Mesityl, $\eta^{1}$-imidazolinylidene-Carbene-Ruthenium(II) complexes: Catalytic activity of their allenylidene derivatives in alkene metathesis and cycloisomerisation reactions. Chem. Eur. J. 2003, 9, 2323. [CrossRef] [PubMed]

53. Arslan, H.; Vanderveer, D.; Özdemir, I.; Çetinkaya, B.; Demir, S. Crystal structure of $\left[\mathrm{RuCl}_{2}[N-\right.$ (2,4,6-trimethyl-benzyl) $N$-(n-butyl)]-imidazolidin-2-ylidene] and $\left[\mathrm{RuCl}_{2}[N-(2,4,6\right.$-trimethyl-benzyl)- $N-(2$ methoxyethyl)]-imidazolidin-2-ylidene]. J. Chem. Crystallogr. 2005, 35, 491-495. [CrossRef]

54. Arslan, H.; VanDerveer, D.; Ozdemir, I.; Yasar, S.; Cetinkaya, B. Dichloro[3-(1-naphthylmethyl)1-(2,4,6-trimethylbenzyl)imidazolidin-2-ylidene]ruthenium. Acta Cryst. E 2005, 61, M1873-M1875. [CrossRef]

55. Bruker, SMART, version 6.12; Bruker AXS Inc.: Madison, WI, USA, 2012.

56. Bruker, SAINT, version 6.12; Bruker AXS Inc.: Madison, WI, USA, 2012.

57. Sheldrick, G.M. A short history of SHELX. Acta Cryst. 2008, A64, 112-122. [CrossRef] [PubMed]

Sample Availability: Samples of the compounds 1a-e and 2a-e are available from the authors.

(C) 2018 by the authors. Licensee MDPI, Basel, Switzerland. This article is an open access article distributed under the terms and conditions of the Creative Commons Attribution (CC BY) license (http://creativecommons.org/licenses/by/4.0/). 